\title{
DIREITOS AMBIENTAIS PROCEDIMENTAIS: ACESSO À INFORMAÇÃO, A PARTICIPAÇÃO PÚBLICA NA TOMADA DE DECISÃO E ACESSO À JUSTIÇA EM MATÉRIA AMBIENTAL
}

\author{
PROCEDURAL ENVIRONMENTAL RIGHTS: ACCESS TO INFORMATION, PUBLIC \\ PARTICIPATION IN DECISION-MAKING AND ACCESS TO JUSTICE IN ENVIRONMENTAL \\ MATTERS
}

DERECHOS AMBIENTALES PROCEDIMENTALES: ACCESO A LA INFORMACIÓN, A LA PARTICIPACIÓN PÚBLICA EN LA TOMA DE DECISIÓN Y ACCESO A LA JUSTICIA EN TEMA AMBIENTAL

Licença CC BY:

Artigo distribuído sob os termos Creative Commons, permite uso e distribuição irrestrita em qualquer meio desde que o autor credite a fonte original.

1

Doutor em Direito pela Universidade de Munique. Estudos em Nível de Pós-Doutorado nas Universidades de Munique (bolsista DAAD), Georgetown e junto ao Instituto Max-Planck de Direito Social Estrangeiro e Internacional (Munique), como bolsista do Instituto, onde também atua como representante brasileiro e correspondente científico. Pesquisador visitante na Harvard Law School (2008). Coordenador do Programa de Pós-Graduação em Direito da PUC-RS. Professor Titular nos cursos de Graduação, Mestrado e Doutorado da PUC-RS e Professor de Direito Constitucional da Escola Superior da Magistratura do RS (AJURIS). Coordenador do Núcleo de Estudos e Pesquisa sobre Direitos Fundamentais (NEDF) da PUC-RS (Sistema de Grupos de Pesquisa do CNPq), vinculado ao Mestrado e Doutorado em Direito da PUC-RS. Autor, entre outras, das obras: $A$ eficácia dos direitos fundamentais (12. ed. Porto Alegre: Livraria do Advogado, 2015), Dignidade da pessoa humana e direitos fundamentais na Constituição Federal de 1988 (10. ed. Porto Alegre: Livraria do Advogado, 2015) e Curso de direito constitucional (6. ed. São Paulo: Saraiva, 2017), esta última em coautoria com Luiz Guilherme Marinoni e Daniel Mitidiero. Desembargador do Tribunal de Justiça do Estado do Rio Grande do Sul.

2 Doutor e Mestre em Direito Público pela PUC-RS (Ex-Bolsista do CNPq), com pesquisa de doutorado-sanduíche junto ao Instituto Max-Planck de Direito Social e Política Social de Munique, na Alemanha (Bolsista da CAPES). Autor das obras Direitos fundamentais e proteção do ambiente (Porto Alegre: Livraria do Advogado, 2008), Defensoria Pública, direitos fundamentais e ação civil pública (São Paulo: Saraiva, 2015) e Defensoria Pública na Constituição Federal (Rio de Janeiro: GEN/Forense, 2017); coautor, juntamente com Ingo Wolfgang Sarlet, das obras Direito constitucional ambiental (5. ed. São Paulo: Revista dos Tribunais, 2017), Direito ambiental: introdução, fundamentos e teoria geral (São Paulo: Saraiva, 2014) e Princípios do direito ambiental (2. ed. São Paulo: Saraiva, 2017); e coautor, juntamente com Ingo Wolfgang Sarlet e Paulo Affonso Leme Machado da obra Constituição e legislação ambiental comentadas (São Paulo: Saraiva, 2015). Defensor Público Estadual (SP). 
(1992) e pela Convenção de Aarhus (1998): participação pública; acesso à informação ambiental; acesso à justiça. Após tal desenvolvimento, os direitos ambientais procedimentais são contextualizados no "no estado da arte" do direito constitucional e infraconstitucional brasileiro, inclusive abordando a atual jurisprudência do Superior Tribunal de Justiça e do Supremo Tribunal Federal sobre a matéria.

Palavras-chave: direito-dever fundamental ao ambiente; dimensão procedimental; direitos ambientais procedimentais; participação pública; acesso à informação ambiental; acesso à justiça.

Abstract: This article focuses on the procedural dimension of the fundamental right-duty to the environment. In light of Fundamental Rights Theory, the procedural environmental rights enshrined in Principle 10 of the Rio Declaration on Environment and Development (1992) and the Aarhus Convention (2008) are analyzed based on the three central thematic axes: access to information, public participation, and access to justice. After this development, the procedural environmental rights are contextualized in the "state of the art" of Brazilian constitutional and infraconstitutional law, including addressing the current jurisprudence of the Superior Court of Justice and the Federal Supreme Court on the matter.

Keywords: fundamental right-duty to the environment; procedural dimension; procedural environmental rights; public participation; access to information; access to justice.

Resumen: El artículo versa sobre la dimensión procedimental del derecho deber fundamental al ambiente. A la luz de la Teoría de los Derechos Fundamentales, son analizados los derechos ambientales procedimentales consagrados por el Principio 10 de la Declaración de Río sobre Medio Ambiente y Desarrollo (1992) y por la Convención de Aarhus (1998): participación pública; acceso a la información ambiental; acceso a la justicia. Después del desarrollo, los derechos ambientales procedimentales son contextualizados "en el estado del arte" del derecho constitucional e infraconstitucional brasileño, incluso abordando la actual jurisprudencia del Superior Tribunal de Justicia y del Supremo Tribunal Federal sobre el tema.

Palabras clave: derecho deber fundamental al ambiente; dimensión procedimental; derechos ambientales procedimentales; participación pública; acceso a la información ambiental; acceso a la justicia.

\section{INTRODUÇÃO}

"A participação pública é baseada no direito das pessoas que podem ser afetadas a terem uma palavra a dizer sobre a determinação do seu futuro ambiental" (Alexandre Kiss e Dinah Shelton). ${ }^{3}$

\section{Os direitos procedimentais, como faceta da própria proteção constitucional} do ambiente e da sua natureza de direito-dever fundamental, apresentam cada vez maior importância no âmbito do Direito Ambiental. Pode-se falar até mesmo

3 KISS, Alexandre; SHELTON, Dinah. Guide to international environmental law. Leiden/Boston: Martinus Hijhoff Publishers, 2007, p. 102. 
de uma "onda renovatória", apropriando-nos da expressão cunhada em obra clássica sobre acesso à justiça por Mauro Cappelletti e Bryant Garth ${ }^{4}$, do marco normativo ambiental capitaneada pelos direitos ambientais procedimentais, também denominados pela doutrina como direitos ambientais de acesso ou direitos ambientais de participação $0^{5}$, cujo escopo maior reside justamente na efetivação da legislação ambiental por meio de uma participação mais ativa da sociedade, exercendo maior controle sobre as práticas poluidoras (ou potencialmente poluidoras) do ambiente perpetradas por agentes públicos e privados.

A consolidação dos direitos ambientais procedimentais é derivada de avanços verificados originariamente no plano internacional, ou seja, no âmbito do Direito Internacional do Meio Ambiente. Não obstante outros precedentes normativos mais remotos também pudessem ser destacados (como a própria Declaração de Estocolmo sobre Meio Ambiente Humano de $1972^{6}$ ), a gênese normativa de tais direitos pode ser atribuída ao Princípio 10 da Declaração do Rio sobre Meio Ambiente e Desenvolvimento (1992). Posteriormente, a Convenção de Aarhus sobre Acesso à Informação, Participação Pública na Tomada de Decisão e Acesso à Justiça em Matéria Ambiental (1998), muito embora o seu espectro limitado inicialmente ao âmbito europeu (mas posteriormente ampliada para o plano global), tratou de forma paradigmática sobre o tema, consagrando a chamada "tríade" dos direitos ambientais procedimentais: acesso à informação, participação pública na tomada de decisão e acesso à justiça. ${ }^{7}$ No ano de 2018, os direitos ambientais procedimentais foram objeto de um Acordo Regional para América Latina e Caribe, com força vinculante, aprovado no âmbito da

4 CAPPELLETTI, Mauro; GARTH, Bryant. Acesso à justiça. Porto Alegre: Fabris, 1988, p. 11-12. Nos anos 70, Mauro Cappelletti capitaneou profunda pesquisa, denominada de "Projeto Florença", sobre a questão do acesso à justiça. Como resultado do estudo científico empreendido, v., além da obra citada, também CAPPELLETTI, Mauro; GORDLEY, James; JOHNSON, Earl. Toward equal Justice: a comparative study of legal aid in modern societies. Milan: Giufre Editore, 1975; e CAPPELLETTI, Mauro (Org.). Acess to Justice and Welfare State. Florença: European University Institute, 1981.

5 A doutrina também utiliza a expressão "direitos humanos procedimentais" (procedural human rights), destacando a tríade de direitos relacionados a tal conceito: acesso à informação, participação pública e acesso à justiça (ANTON, Donald K.; SHELTON, Dinah L. Environmental protection and human rights. Cambridge: Cambridge University Press, 2011, p. 356 e ss.). Na doutrina brasileira, acerca dos direitos ambientais procedimentais, v. MIRRA, Álvaro Luiz Valery. Participação, processo civil e defesa do meio ambiente. São Paulo: Letras Jurídicas, 2011.

6 V. COMISSÃO MUNDIAL SOBRE MEIO AMBIENTE E DESENVOLVIMENTO. Relatório Nosso Futuro Comum. 2.ed. São Paulo: Editora da Fundação Getúlio Vargas, 1991, p. 365.

7 Para uma breve introdução à Convenção de Aarhus, v. EBBESSON, Jonas. "Acesso à informação, participação pública e acesso à justiça em matéria ambiental: uma breve introdução à Convenção de Aarhus". In: Revista de Direito Ambiental, v. 64, São Paulo, Revista dos Tribunais, Out.-Dez., 2011, p. 35 e ss. 
Comissão Econômica para a América Latina e o Caribe (CEPAL) da Organização das Nações Unidas (ONU). ${ }^{8}$

No cenário jurídico brasileiro, a fonte normativa primária dos direitos ambientais procedimentais pode ser extraída da própria Constituição Federal de 1988, mais precisamente do conteúdo expresso do seu art. 225. Ao consagrar os deveres de proteção estatais e o direito fundamental ao ambiente ${ }^{9}$, o caput do dispositivo em questão enuncia, para além do direito em si, o dever fundamental (ou deveres fundamentais) da sociedade, ou seja, dos particulares "de defendêlo e preservá-lo para as presentes e futuras gerações". Não por outra razão, a doutrina identifica a natureza de direito-dever fundamental inerente ao regime constitucional de proteção ambiental. ${ }^{10}$ Há, em outras palavras, verdadeiro dever jurídico (e não apenas moral) de proteção ambiental atribuído aos cidadãos (e, portanto, não apenas ao Estado), o qual deve ser exercido por meio de uma maior participação e controle pela sociedade acerca das práticas que atentam contra o equilíbrio ecológico. ${ }^{11}$ Em outras palavras, como destaca a doutrina, os direitos ambientais procedimentais conduzem a uma espécie de "cidadania ambiental responsável" ("responsible environmental citizenship"). ${ }^{12}$

8 Disponível em: https://www.cepal.org/pt-br/comunicados/america-latina-o-caribe-adotam-seu-primeiro-acordoregional-vinculante-protecao-direitos. Acesso em: 21 de março de 2018.

9 Sobre o reconhecimento do direito ao ambiente como autêntico direito fundamental, inclusive no sentido de se servir do mesmo regime constitucional dispensado aos direitos liberais e sociais, v. FENSTERSEIFER, Tiago. Direitos fundamentais e proteção do ambiente: a dimensão ecológica da dignidade da pessoa humana no marco jurídico constitucional do estado socioambiental de direito. Porto Alegre: Livraria do Advogado, 2008; e, mais recentemente, SARLET, Ingo Wolfgang; FENSTERSEIFER, Tiago. Direito constitucional ambiental: Constituição, direitos fundamentais e proteção do ambiente. 5.ed. São Paulo: Revista dos Tribunais, 2017.

10 Sobre o tema dos deveres fundamentais em matéria ambiental, v. SARLET; FENSTERSEIFER, Direito constitucional ambiental..., especialmente p. 237-288; e FENSTERSEIFER, Direitos fundamentais e proteção do ambiente..., p. 198-219. Na doutrina estrangeira, a empreitada de desenvolver uma teoria geral dos deveres fundamentais de proteção do ambiente em língua portuguesa foi realizada, de forma original e exemplar, por GOMES, Carla Amado. Risco e modificação do ato autorizativo concretizador de deveres de proteção do ambiente. Coimbra: Coimbra Editora, 2007, especialmente nas p. 151 e ss.

11 No âmbito do direto comparado, merece destaque a consagração dos direitos ambientais procedimentais na Constituição da Finlândia (1999), precisamente na Seção 20 (Responsabilidade para com o meio ambiente) do Capítulo 2 que trata dos "Direitos básicos e liberdades" (Chapter 2 - Basic rights and liberties). No caso, verificouse o reconhecimento expresso do direito de participar (e influenciar) nas decisões públicas concernentes ao meio ambiente ("Section 20 - Responsibility for the environment. Nature and its biodiversity, the environment and the national heritage are the responsibility of everyone. The public authorities shall endeavour to guarantee for everyone the right to a healthy environment and for everyone the possibility to influence the decisions that concern their own living environment). Disponível em: http://www.finlex.fi/en/laki/kaannokset/1999/en19990731. pdf. Acesso em: 26 de outubro de 2017.

12 PALLEMAERTS, Marc. "Proceduralizing environmental rights: the Aarhus Convention on Access to Information, Public Participation in Decision-Making and Access to Justice in Environmental Matters in a Human Rights Context". In: Human Rights and the Environment: Proceedings of a Geneva Environment Network roundtable. Genebra: UNEP, 2004, p. 19. Disponível em: http://www.genevaenvironmentnetwork.org/?q=en/publications. Acesso em 25 de outubro 2017. 
Os direitos ambientais procedimentais, à luz desse regime constitucionalambiental, criam condições reais para que os deveres fundamentais de proteção ambiental referidos sejam operacionalizados pelos particulares (e, de certa forma, também pelas instituições públicas intermediárias encarregadas de prover a defesa ecológica em prol de toda a coletividade, como é o caso, em especial, do Ministério Público, bem como no tocante aos grupos sociais necessitados ou vulneráveis, também da Defensoria Pública), além de permitir, é claro, a própria salvaguarda do direito fundamental ao ambiente na hipótese de ameaça de violação ou violação. Os mecanismos de controle e participação da sociedade proporcionados por tais direitos ou posições jurídicas subjetivas derivados dos direitos ambientais procedimentais configuram importante instrumento a serviço dos indivíduos e das entidades associativas protetoras do ambiente para exigir o estrito cumprimento da legislação ambiental por parte de agentes públicos e privados.

\section{TEORIA DOS DIREITOS FUNDAMENTAIS E DIREITOS AMBIENTAIS PROCEDIMENTAIS: A DIMENSÃO PROCEDIMENTAL DO DIREITO FUNDAMENTAL AO AMBIENTE}

Ao passo que a preocupação do mundo jurídico volta-se cada vez mais para a efetivação dos direitos, não se satisfazendo com a sua mera proclamação em belos textos legislativos (a exemplo da CF/88), conforme já nos alertou Norberto Bobbio em passagem clássica ${ }^{13}$, ganha maior relevância a dimensão organizacional e procedimental dos direitos fundamentais ou mesmo a ideia de proteção dos direitos fundamentais por meio do(s) procedimento(s) (Grundrechtschutz durch Verfahren). ${ }^{14} \mathrm{Em}$ alguns aspectos, não deixa de se tratar de uma releitura do status activus dos direitos fundamentais, tal qual proposto por Georg Jellinek, na forma de um atualizado status activus processualis como defendido por Peter Häberle ${ }^{15}$. O olhar dos juristas contemporâneos está focado mais do que nunca nos mecanismos necessários à transposição dos direitos proclamados nos textos legais para o "mundo da vida". Os denominados direitos procedimentais cumprem justamente tal função, operando no sentido da efetivação dos direitos ditos "materiais".

\footnotetext{
13 BOBBIO, Norberto. A era dos direitos. 10.ed. Rio de Janeiro: Campus, 1992, p. 9-10.

14 HUFEN, Friedhelm. Staatsrecht II: Grundrechte. 4.ed. Munique: C.H.Beck, 2014, p. 58.

15 HÄBERLE, Peter. "Grundrechte im Leistungsstaat". In: VVDStRL, 1972, p. 81 e ss.
} 
Ocorre que, de tão importantes que são para o exercício dos direitos materiais, ou seja, para lhes conferir efetividade, os direitos procedimentais também alcançam status jusfundamental, sendo incorporados ao núcleo do regime constitucional. O instrumento-procedimento revela-se, nesse sentido, quase tão importante quanto o direito material em si, ou seja, o fim a que ele visa conferir proteção. Esse é, por exemplo, o caso do direito fundamental à assistência jurídica (ou, num sentido mais amplo, do acesso à justiça ${ }^{16}$ ). Num mundo ideal onde o exercício dos direitos (sobretudo os de natureza fundamental) é pleno, a razão de existir dos direitos procedimentais desaparece. Todavia, no mundo real, as violações de direitos fundamentais são constantes, inclusive no que diz respeito àqueles mais básicos e elementares ao desfrute de uma vida minimamente digna, entre os quais o direito a viver em um ambiente sadio, equilibrado e seguro.

A função outorgada aos direitos fundamentais como parâmetro para a configuração de organizações (ou instituições) estatais e procedimentos voltados à sua proteção e efetivação é tida pela doutrina como desdobramento da perspectiva ou dimensão objetiva de tais direitos, o que permite, com base no conteúdo das normas de direitos fundamentais, que se extraiam consequências para a aplicação e interpretação das normas procedimentais, mas também para uma formatação do direito organizacional e procedimental que auxilie na efetivação da proteção aos direitos fundamentais. ${ }^{17}$ O jurista alemão Konrad Hesse destaca o desenvolvimento recente e progressivo da dimensão organizacional e procedimental dos direitos fundamentais, em vista de uma preocupação com a realização e o asseguramento desses..$^{18} \mathrm{~A}$ importância de tal perspectiva resulta do fato de que a efetivação dos direitos fundamentais depende, em grande parte, da implementação por parte dos poderes públicos de estruturas organizacionais

16 A título de exemplo, o acesso à justiça é reconhecido como integrante do direito-garantia ao mínimo existencial, muito embora com natureza instrumental. Na doutrina, sustentando que o direito à assistência jurídica integra 0 conteúdo do mínimo existencial, não obstante a referência seja muitas vezes ao acesso à justiça em sentido mais amplo, v. TORRES, Ricardo Lobo. O direito ao mínimo existencial. Rio de Janeiro: Renovar, 2009, p. 269 e 282; BARCELLOS, Ana Paula de. A eficácia jurídica dos princípios constitucionais: o princípio da dignidade humana. 2.ed. Rio de Janeiro/São Paulo/Recife: Renovar, 2008, p. 325 e 330-331; e BITENCOURT NETO, Eurico. O direito ao mínimo para uma existência digna. Porto Alegre: Livraria do Advogado, 2010, p. 269. Em reforço a tal perspectiva, Bitencourt Neto sustenta ser a Defensoria Pública expressão de "norma organizatória e procedimental" conformadora do âmbito de proteção do direito ao mínimo existencial (p. 124).

17 SARLET, Ingo W. A eficácia dos direitos fundamentais: uma teoria geral dos direitos fundamentais na perspectiva constitucional. 12.ed. Porto Alegre: Livraria do Advogado, 2015, p. 156 e ss.

18 HESSE, Konrad. Elementos de direito constitucional da República Federal da Alemanha. Porto Alegre: Sergio Antônio Fabris Editor, 1998, p. 287. 


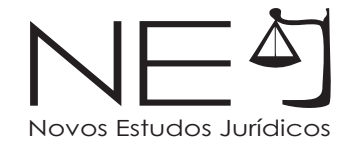

e procedimentos (administrativos, judiciais, etc.) capazes de garantir o seu pleno exercício e gozo por parte dos seus titulares.

Há, em certa medida, uma convergência e conexão entre os deveres de proteção do Estado e as perspectivas organizacional e procedimental, em razão de que as duas facetas da perspectiva ou dimensão objetiva dos direitos fundamentais conformam a adoção de normas dispondo sobre o procedimento administrativo e judicial, bem como pela criação de órgãos, objetivando ambas as perspectivas normativas um procedimento ordenado e justo para a efetivação ou garantia eficaz dos direitos fundamentais. ${ }^{19}$ Assim, a implementação de estruturas organizacionais e de procedimentos judiciais e administrativos por parte do Estado tem como fundamento também o dever de proteção do ente estatal em face dos direitos fundamentais, tendo em vista que a tutela adequada e realização desses demanda um conjunto de medidas tomadas no plano fático e estrutural do Estado, como a criação de órgãos encarregados de promover políticas públicas de efetivação do direito ou dos mecanismos administrativos e judiciais capazes de afastar qualquer violação ao direito (ou mesmo ameaça de violação).

Ambas as projeções normativas extraídas da dimensão objetiva dos direitos fundamentais - o dever de proteção do Estado e as perspectivas organizacional e procedimental - complementam-se na teia normativa traçada pela Teoria dos Direitos Fundamentais para tutela dos valores basilares da comunidade estatal em vista da sua efetivação. Não obstante a relevância da dimensão organizacional, ou seja, a criação de instituições e organizações no plano estatal para assegurar a efetivação dos direitos fundamentais, é a dimensão procedimental dos direitos fundamentais que mais nos interessa para o desenvolvimento dos direitos ambientais procedimentais, já que esta última é que diz respeito diretamente à conformação de procedimentos e instrumentos administrativos e judiciais voltados à efetivação dos direitos fundamentais e, no caso do nosso estudo, do direito fundamental ao ambiente. ${ }^{20}$ A função do direito ao procedimento é instrumentalizar e garantir uma proteção efetiva dos direitos materiais, determinando posições jurídicas subjetivas frente ao Estado e a particulares,

19 SARLET, A eficácia dos direitos fundamentais..., p. 156.

20 Para maiores desenvolvimentos sobre a perspectiva procedimental e organizacional do direito fundamental ao ambiente, v. FENSTERSEIFER, Direitos fundamentais e proteção do ambiente..., p. 231 e ss. 
ademais de viabilizar, em algumas situações, também a participação pública na tomada de decisão (por parte do Estado-Legislador e do Estado-Administrador) que afeta o âmbito de proteção dos direitos fundamentais.

Esse é o entendimento de Robert Alexy, para quem os direitos a procedimentos judiciais e administrativos são essencialmente direitos a uma "proteção jurídica efetiva", objetivando por intermédio do procedimento a garantia dos direitos materiais do seu respectivo titular. ${ }^{21}$ Não é diferente o entendimento de Luiz G. Marinoni, ao afirmar que "o direito fundamental de ação pode ser concebido como um direito à fixação das técnicas processuais idôneas à efetiva tutela do direito material". ${ }^{22} \mathrm{O}$ direto ao procedimento, judicial e administrativo, opera como projeção do próprio direito material, já que busca conferir a esse uma tutela integral e efetiva. Alinhado à "doutrina da norma de proteção", Vasco Pereira da Silva pontua que o dever do Estado de assegurar a eficácia dos direitos fundamentais, tanto por intermédio do procedimento administrativo quanto do processo judicial, coloca nas mãos do indivíduo um direito subjetivo a exigir do Estado o cumprimento de tais regras processuais e procedimentais. ${ }^{23}$ Verificase, portanto, a configuração de um verdadeiro dever do Estado no sentido de criar tais vias procedimentais necessárias à efetivação do direito fundamental ao ambiente e, da mesma forma, assegurar a participação pública em tais questões, tanto na esfera administrativa quanto judicial. Ao Estado cabe promover a fruição adequada desses direitos ambientais procedimentais por parte do público interessado, tanto pelo prisma individual quanto coletivo.

Nesse sentido, e já na perspectiva da proteção constitucional do ambiente, J. J. Gomes Canotilho assinala que os "direitos ambientais procedimentais", independentemente do reconhecimento de um direito fundamental ao ambiente como direito subjetivo, expressam-se sob a forma de direitos de informação, direitos de participação e direitos de ação judicial. ${ }^{24}$ Outro aspecto que também deve ser considerado na fundamentação dos direitos ambientais procedimentais (e não por outra razão também são designados por alguns como "direitos de 21 ALEXY, Robert. Teoria dos direitos fundamentais. São Paulo: Malheiros, 2008, p. 488.

22 MARINONI, Luiz Guilherme. Teoria Geral do Processo. São Paulo: Revista dos Tribunais, 2006, p. 207.

23 PEREIRA DA SILVA, Vasco. Verde cor de direito: lições de Direito do Ambiente. Coimbra: Almedina, 2002, p. 138, nota 2.

24 CANOTILHO, J. J. Gomes. "O direito ao ambiente como direito subjetivo”. In: CANOTILHO, José Joaquim Gomes. Estudos sobre Direitos Fundamentais. Coimbra: Coimbra Editora, 2004, p. 187. 
participação") diz respeito ao seu papel na conformação da vontade estatal em temas ambientais. Afinal de contas, novamente trazendo o entendimento de Alexy, "a participação cria juridicamente a possibilidade fática de uma influência no processo de formação da vontade estatal no que diz respeito à proteção do direito fundamental". ${ }^{25}$ De tal sorte, além da faceta "protetiva" inerente aos direitos ambientais procedimentais, instrumentalizando medidas voltadas à salvaguarda do direito em situações de lesão ou ameaça de lesão, também se pode destacar uma faceta "participativa", de modo a influenciar a decisão estatal que repercuta da esfera de proteção do direito fundamental ao ambiente.

O direito fundamental ao ambiente, conforme a lição de Alexy, caracterizase como um "direito fundamental completo ou mesmo um direito fundamental em sentido amplo", abarcando um feixe complexo e abrangente de posições jurídicas. De acordo com o autor alemão, conjuntamente com as posições jurídicas derivadas da sua configuração como direito de defesa (dimensão negativa ou em face do Estado para que se abstenha de degradar o ambiente), como direito à proteção (imposta ao Estado frente a intervenções lesivas ao ambiente praticadas por terceiros) e como direito à prestação fática (dimensão positiva ou prestacional imposta ao Estado para promover medidas fáticas voltadas à tutela ecológica), emerge do regime jurídico-constitucional do direito fundamental ao ambiente também a sua dimensão como direito a procedimentos, ou seja, "um direito a que o Estado inclua o titular do direito fundamental nos procedimentos relevantes para o meio ambiente". ${ }^{26}$ É a perspectiva ou dimensão procedimental do direito fundamental ao ambiente a que se refere Alexy. Os direitos ambientais procedimentais podem ser concebidos como concretizações de tal dimensão procedimental, dada a sua importância para a salvaguarda do direito fundamental ao ambiente em si.

Lançado esse olhar panorâmico e introdutório sobre o tema, sobretudo pelo prisma da Teoria dos Direitos Fundamentais, iremos migrar para uma análise mais pontual da "tríade" de direitos conformadora da dimensão procedimental do direito-dever fundamental ao ambiente, ou seja, o acesso à informação, a participação pública na tomada de decisões e o acesso à justiça, contextualizando com cenário jurídico brasileiro. 


\section{DIREITOS AMBIENTAIS PROCEDIMENTAIS EM ESPÉCIE}

"Princípio 10. A melhor maneira de tratar as questões ambientais é assegurar a participação, no nível apropriado, de todos os cidadãos interessados. No nível nacional, cada indivíduo terá acesso adequado às informações relativas ao meio ambiente de que disponham as autoridades públicas, inclusive informações acerca de materiais e atividades perigosas em suas comunidades, bem como a oportunidade de participar dos processos decisórios. Os Estados irão facilitar e estimular a conscientização e a participação popular, colocando as informações à disposição de todos. Será proporcionado o acesso efetivo a mecanismos judiciais e administrativos, inclusive no que se refere à compensação e reparação de danos" (Declaração de Rio sobre Meio Ambiente e Desenvolvimento de 1992)

\subsection{CONSIDERAÇÕES INTRODUTÓRIAS: A TRÍADE DOS DIREITOS AMBIENTAIS PROCEDIMENTAIS}

A Declaração de Estocolmo sobre Meio Ambiente Humano (1972), embora de forma ainda incipiente, já tratou de lançar as primeiras linhas sobre a necessidade de participação dos cidadãos e das comunidades e, portanto, não apenas dos Estados, na proteção ambiental. No item 7 do seu Preâmbulo, resultou consignado que, para alcançar a meta de defesa e melhoramento do meio ambiente humano para as gerações presentes e futuras, "será necessário que cidadãos e comunidades, empresas e instituições, em todos os planos, aceitem as responsabilidades que possuem e que todos eles participem equitativamente, nesse esforço comum. Homens de toda condição e organizações de diferentes tipos plasmarão o meio ambiente do futuro, integrando seus próprios valores e a soma de suas atividades. (...) A Conferência encarece aos governos e aos povos que unam esforços para preservar e melhorar o meio ambiente humano em benefício do homem e de sua posteridade". A grande maioria dos diplomas internacionais e domésticos editados após a Declaração de Estocolmo seguiram esse mesmo panorama e também se encarregaram, em maior ou menor medida, de estimular e participação pública em matéria ambiental.

Essa característica "democrático-participativa" inerente à legislação ambiental desde os seus primórdios, tanto no plano internacional quanto nacional, pode 
ser compreendida até mesmo por força da politização do movimento ecológico verificada especialmente a partir da Década de 1970 (período que coincide com o surgimento do Direito Ambiental), com uma articulação cada vez maior de grupos da sociedade (associações ambientalistas) voltados à proteção da Natureza no cenário político (doméstico e internacional), reivindicando instrumentos (legislativos, administrativos e judiciais) voltados a propiciar uma maior participação pública, controle social e intervenção direta na tomada de decisões políticas de índole ecológica.

O Princípio 10 da Declaração do Rio (1992), nesse percurso evolutivo, tornouse, sem dúvida, a norma internacional referencial para a conformação do conteúdo inerente ao princípio da participação pública em questões envolvendo a tutela ecológica, dando contornos conceituais aos direitos ambientais procedimentais. No dispositivo citado, é possível identificar os três elementos-chave ou pilares que concretizam os direitos ambientais procedimentais: a) acesso à informação; b) participação pública na tomada de decisões; e c) acesso à justiça. Posteriormente, como já referido na abertura do presente texto, a Convenção de Aarhus sobre Acesso à Informação, Participação Pública na Tomada de Decisão e Acesso à Justiça em Matéria Ambiental (1998) tratou de forma paradigmática sobre o tema, consagrando e detalhando a referida "tríade" dos direitos ambientais procedimentais. ${ }^{27}$ No ano de 2018 , os direitos ambientais procedimentais foram objeto de um Acordo Regional para América Latina e Caribe, com força vinculante, aprovado no âmbito da Comissão Econômica para a América Latina e o Caribe (CEPAL) da ONU. ${ }^{28}$

Os três elementos que conformam os direitos ambientais procedimentais estão sobremaneira conectados e apresentam conteúdos normativos, tanto de ordem material quanto procedimental, interdependentes. Isso se pode perceber especialmente na relação entre participação pública na tomada de decisões e acesso à informação, sendo este último pré-requisito para que a participação

27 Na doutrina europeia, a respeito da Convenção de Aarhus e dos direitos ambientais procedimentais, com referência às diretivas europeias sobre o tema, v. BERTHIER, A.; KRÄMER. The Aarhus Convention: Implementation and Compliance in European Union Law. Bruxelas: ClientEarth, 2014; e SCHLACKE, Sabine; SCHRADER, Christian; BUNGE, Thomas. Informationsrechte, Öffentlichkeitsbeteiligung und Rechtsschutz im Umweltrecht (AarhusHandbuch). Berlin: Erich Schmidt Verlag, 2010.

28 Disponível em: https://www.cepal.org/pt-br/comunicados/america-latina-o-caribe-adotam-seu-primeiro-acordoregional-vinculante-protecao-direitos. Acesso em: 21 de março de 2018. 
pública se dê de modo qualificado e efetivo, o que só se faz possível com o acesso à informação ambiental existente no âmbito dos órgãos públicos tomadores da decisão (e, em algumas circunstâncias, também as informações ambientais em poder de particulares). Do contrário, a participação não será efetiva, por mais que formalmente assegurada. O mesmo podemos dizer em relação ao acesso à justiça, inclusive como forma de reivindicar o exercício dos demais direitos ambientais procedimentais na hipótese de violação ou restrição indevida, conforme veremos à frente. Feitas as primeiras considerações sobre o tema à luz das três categorias centrais conformadoras dos direitos ambientais procedimentais, iremos, a partir de agora, analisar cada uma delas de forma específica, iniciando-se pela participação pública no processo de tomada de decisões em matéria ambiental.

\subsection{A PARTICIPAÇÃO PÚBLICA NO PROCESSO DE TOMADA DE DECISÕES EM MATÉRIA AMBIENTAL}

O direito à participação pública em matéria ambiental, num olhar mais panorâmico, pode ser considerado como derivado do próprio direito fundamental à participação política, consagrado, entre inúmeros outros dispositivos internacionais, no art. 21 da Declaração Universal dos Direitos Humanos (1948), no art. 25 do Pacto Internacional dos Direitos Civis e Políticos (1966) e no art. 23 da Convenção Americana sobre Direitos Humanos (1969). No âmbito constitucional brasileiro, o direito (e também dever) à participação política está inscrito nos arts. $1^{\circ}$ (inciso II e parágrafo único) e 14 e ss. da CF/88, cuidando-se de direitos fundamentais de participação política. Não por outra razão, Jonas Ebbesson destaca a relação entre os direitos de participação em matéria ambiental com o Direito Internacional dos Direitos Humanos. Para o autor, todo o aporte e desenvolvimento teórico e jurisprudencial já assegurado no âmbito dos direitos humanos sobre a questão da participação pública também deve ser utilizado no âmbito ecológico (assim como - acrescentamos - no tocante ao acesso à informação e ao acesso à justiça). ${ }^{29}$

Ao tratarmos da questão da participação "pública" em matéria ambiental, é fundamental estabelecer a conceituação do "público", ou seja, quem seria o $\overline{29}$ EBBESSON, Jonas. “Public participation”. In: BODANSKY, Daniel; BRUNNÉE, Jutta; HEY, Ellen (Edit.). The Oxford Handbook of International Environmental Law. New York: Oxford University Press, 2007, p. 687. 


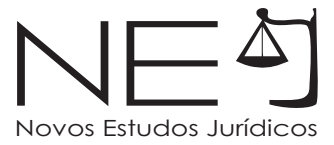

beneficiário dos respectivos mecanismos de participação. Quem é o "público", ou seja, quem são os atores não estatais a que se dirigem as disposições voltadas à participação pública ambiental? Respondendo a essa pergunta, Jonas Ebesson afirma que "o público" é definido de forma negativa, ou seja, todos os atores que não integram o poder público em geral (Public Administration). Incluem-se, portanto, como integrantes do "público" os indivíduos, grupos, organizações não governamentais, movimentos sociais, povos indígenas e comunidades locais, os quais não se encontram vinculados ao governo ou ao poder público em geral. ${ }^{30}$ Esse entendimento, a nosso ver, está em sintonia com o próprio caput do art. 225 $\mathrm{da} \mathrm{CF} / 88$, ao dispor que incumbe ao Estado e à coletividade o dever de proteger o ambiente, tudo a apontar para o fato de que o conceito de coletividade adotado pelo texto constitucional brasileiro pode ser tido como abarcando os sujeitos indicados por Ebesson na passagem citada.

Muito embora o conceito de "público" seja amplo, há, na seara ambiental, tanto em âmbito nacional quanto internacional, verdadeiro protagonismo das organizações não governamentais ambientais ${ }^{31}$, não obstante a participação individual das pessoas também ocorrer em diversas situações, inclusive no campo da reivindicação judicial da proteção do ambiente (como ocorre, no ordenamento jurídico brasileiro, por intermédio do ajuizamento de ações populares). A importância das organizações não governamentais (e também das entidades científicas) foi ressaltada no Relatório Nosso Futuro Comum (1987). De acordo com o documento, "os grupos científicos e as ONGs desempenharam papel de destaque no movimento em prol do meio ambiente desde o início", de modo que "as organizações não governamentais e grupos de cidadãos foram pioneiros no despertar da consciência pública e na iniciativa de pressões políticas que estimularam os governos a agir". ${ }^{32}$ Resultou consignado também no documento que "é preciso que os governos reconheçam e ampliem o direito das ONGs de possuir e ter acesso a informações sobre o meio ambiente e os recursos naturais, bem como seu direito de serem consultadas e de participarem das decisões

30 EBBESSON, Public participation..., p. 685.

31 Na doutrina comparada, a respeito da importância e do papel das associações civis de defesa do ambiente, $v$. PRIEUR, Michel. Droit de l'environnement. 6.ed. Paris: Dalloz, 2011, p. 137 e ss.

32 COMISSÃO MUNDIAL SOBRE MEIO AMBIENTE E DESENVOLVIMENTO. Relatório Nosso Futuro Comum..., p. 365. 
sobre atividades que podem ter efeitos significativos sobre seu meio ambiente, e de disporem de recursos legais para serem indenizadas quando a saúde das pessoas e meio ambiente forem seriamente afetados". ${ }^{33}$

A Agenda 21 (item 27, § $1^{\circ}$ ), reforçando esse entendimento, assinala que "as organizações não governamentais desempenham um papel fundamental na modelagem e implementação da democracia participativa. A natureza do papel independente desempenhado pelas organizações exige uma participação genuína; portanto, a independência é um atributo essencial dessas organizações e constitui condição prévia para a participação genuína". Nessa linha, Vasco Pereira da Silva acentua a importância da atuação das associações de defesa do ambiente, afirmando que "a proteção jurídica subjetiva, garantida pela Constituição e pelas normas jurídicas, em matéria ambiental, tanto se refere ao indivíduo como a associações representativas dos seus direitos ou interesses... Tais associações atuam, assim, como verdadeiros sujeitos das relações ambientais, para a defesa das respectivas posições jurídicas subjetivas, de acordo com os seus fins estatutários". ${ }^{4}$ Ainda a respeito do tema, Inês de Souza Dias e João Paulo Capobianco asseveram que "a legislação ambiental e os mecanismos que permitem a participação popular nos processos decisórios são, sem dúvida, uma das principais armas do movimento ambientalista no caso de obras e empreendimentos que envolvam grandes interesses econômicos e políticos". 35

O exemplo das organizações não governamentais ecológicas coloca em debate não apenas os direitos de participação, mas também os deveres de participação e proteção do ambiente. Retomando ponto já tratado anteriormente, cabe frisar que a proteção constitucional do ambiente, para além de um direito fundamental, também é caracterizada pela configuração de um ou vários deveres fundamentais de proteção do ambiente a cargo dos próprios titulares do direito ao ambiente, tanto pelo prisma individual quanto coletivo. O direito ao ambiente possui, portanto, uma natureza peculiar de direito-dever fundamental. Assim, além dos deveres estatais de proteção ambiental, arrolados exemplificativamente no § 33 COMISSÃO MUNDIAL SOBRE MEIO AMBIENTE E DESENVOLVIMENTO, Relatório Nosso futuro comum..., p. 367.

34 PEREIRA DA SILVA, Verde cor de direito..., p. 29.

35 DIAS, Inês de Souza; CAPOBIANCO, João Paulo. "As organizações não-governamentais e a legislação ambiental: a experiência da Fundação SOS Mata Atlântica”. In: BENJAMIN, Antônio Herman (Coord.). Dano ambiental: prevenção, reparação e repressão. São Paulo: Revista dos Tribunais, 1993, p. 394. 
$1^{\circ}$ do art. 225 da CF/88, há a consagração constitucional de deveres fundamentais atribuídos aos particulares. Essa constatação reflete justamente na perspectiva da participação pública em matéria ambiental, podendo a mesma ser caracterizada como um dever inerente à condição político-jurídica de cidadão, inclusive levando em conta a concepção de uma cidadania ambiental ou ecológica. Dito de outro modo, a passividade e a inércia política do cidadão, quando confrontado com uma situação concreta de lesão ou ameaça de lesão ao ambiente, contrariam o regime jurídico-constitucional delineado pelo art. 225 da CF/88.

Por outro lado, resulta evidente que uma postura proativa dos indivíduos e das organizações não governamentais (além dos movimentos populares, etc.) em relação à participação política em matéria ambiental depende, em grande medida, da existência de mecanismos legislativos, administrativos e judiciais capazes de dar concretização e efetividade ao protagonismo da sociedade, o que torna fundamental a atuação do Estado no sentido de criar tais instrumentos participativos. No caso de tais instrumentos existirem e de serem colocados à disposição dos cidadãos, no plano individual e coletivo, seria mesmo possível cogitar da existência de um correspondente dever jurídico de participação (e, portanto, não apenas de caráter moral) no sentido de os mesmos participarem (ativamente) no processo decisório em matéria ecológica, além, é claro, de contribuírem para a fiscalização e o controle de práticas públicas e privadas de caráter antiecológico. A eficácia social da legislação ambiental brasileira é em grande parte dependente do protagonismo da sociedade civil (organizada e também não organizada), inclusive pelo prisma da atuação individual de cada pessoa (por exemplo, denunciado às autoridades públicas competentes as práticas lesivas ao ambiente que chegam ao seu conhecimento).

$\mathrm{O}$ art. 70, § $2^{\circ}$, da Lei dos Crimes e Infrações Administrativas Ambientais (Lei 9.605/98) bem ilustra essa condição político-participativa dos cidadãos em matéria ambiental, ao reconhecer que "qualquer pessoa, constatando infração ambiental, poderá dirigir representação às autoridades relacionadas no parágrafo anterior, para efeito do exercício do seu poder de polícia", bem como, de modo complementar, no $\S 3^{\circ}$ do mesmo dispositivo, que "autoridade ambiental que tiver conhecimento de infração ambiental é obrigada a promover a sua apuração imediata, mediante 
processo administrativo próprio, sob pena de corresponsabilidade". Ou seja, além do próprio caput do art. 225 da CF/88, que estabelece o dever da coletividade no tocante à proteção ambiental, a legislação infraconstitucional também se encarrega de estabelecer um regime jurídico adequado para a participação ativa dos cidadãos na proteção ambiental. A Lei da Ação Popular (Lei 4.717/65, com a inclusão da proteção ambiental no seu objeto levado a efeito pelo art. 50, LXXIII, da CF/88), a Lei da Ação Civil Pública (Lei 7.347/85), a Lei de Acesso à Informação Ambiental (Lei 10.650/2003) e a Lei do Acesso à Informação Pública (Lei 12.527/2011) são bons exemplos normativos desse paradigma participativo ecológico, pois colocam ao acesso do público interessado mecanismos de acesso à informação, controle administrativo e judicial e participação em temas afetos ao ambiente.

O princípio da participação pública, por sua vez, aparece consagrado em diversos dispositivos dalegislação ambiental brasileira no plano infraconstitucional. De modo pioneiro, a Lei da Política Nacional do Meio Ambiente (Lei 6.938/81) estabeleceu, no seu art. 4ㅇ, V, como objetivos PNMA a "difusão de tecnologias de manejo do meio ambiente, à divulgação de dados e informações ambientais e à formação de uma consciência pública sobre a necessidade de preservação da qualidade ambiental e do equilíbrio ecológico". A Lei da Mata Atlântica (Lei $11.428 / 2006)$ consagra, no seu art. $6^{\circ}$, parágrafo único, como princípios norteadores do seu regime jurídico, a transparência das informações e atos, a gestão democrática, a celeridade procedimental e a gratuidade dos serviços administrativos prestados ao pequeno produtor rural e às populações tradicionais. A Lei da Política Nacional sobre Mudança do Clima (Lei 12.187/2009) reconhece, no seu art. $3^{\circ}$, caput, como princípio da PNMC, a participação cidadã. A Lei da Política Nacional de Resíduos Sólidos (Lei 12.305/2010), com o mesmo propósito, arrola como princípio da PNRS, a "cooperação entre as diferentes esferas do poder público, o setor empresarial e demais segmentos da sociedade" (inciso VI), e o "direito da sociedade à informação e ao controle social" (inciso X).

No tocante aos instrumentos legislativos de participação pública ambiental, registram-se, entre outros, além do direito de sufrágio ativo e passivo, a iniciativa popular de lei (arts. 14, III, 29, XIII, e 61, § 20 , da CF/88), o plebiscito (art. 14, I, da CF/88 e Lei 9.709/98) e o referendo (art. 14, I, da CF/88 e Lei 9.709/98I). Muito 


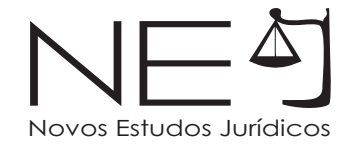

embora não tenhamos visto com frequência a utilização desses instrumentos de participação na nossa práxis política, com exceção, por óbvio, do tradicional direito de voto para escolha dos cargos eletivos do legislativo e executivo, é possível a utilização dos mesmos com propósitos ecológicos. Com efeito, seria perfeitamente possível lançar mão da iniciativa popular para a apresentação de projetos de leis complementares ou ordinárias (federais, estaduais ou municipais) com conteúdo ecológico, bem como a realização de referendo sobre uma lei relacionada com a proteção do ambiente ou mesmo plebiscito a respeito de alguma temática ecológica específica que ainda não tenha sido objeto de regulamentação. Precisamente a respeito da iniciativa legislativa, Édis Milaré assinala que "a admissão da iniciativa popular de lei é um dos aspectos fundamentais trazidos pela legislação, principalmente em função da especificidade técnica das matérias que envolvem a questão ambiental. Dessa forma, as entidades ambientalistas e a comunidade científica em geral passam a ter a oportunidade de contribuir efetiva e concretamente para a solução dos problemas ambientais e também para a evolução do direito e da legislação sobre o meio ambiente". ${ }^{36}$

Ainda na seara legislativa, como expressão da participação pública ecológica, destacamos a criação de partidos políticos com o objetivo de defender no cenário político a bandeira ecológica. Talvez o melhor exemplo disso seja a criação do Partido Verde, verificada no início da Década de 1980, na Alemanha, que serviu de inspiração para iniciativas similares em muitos outros países, inclusive o Brasil (no ano de 1986). ${ }^{37}$ A existência de partidos políticos "ecológicos" permite a ocupação de um espaço político extremamente relevante para fortalecer a causa ambiental e produzir modificações significativas no plano institucional (legislativo, administrativo e judiciário) do Estado. No trâmite dos projetos de lei que tenham como objeto a matéria ambiental, também devemos oportunizar a participação dos interessados, sobretudo das associações ambientalistas, cabendo às casas legislativas promover audiências públicas (por exemplo, no âmbito das comissões temáticas sobre meio ambiente existente nos nossos parlamentos 36 MILARÉ, Édis. Direito do ambiente. 8.ed. São Paulo: Revista dos Tribunais, 2013, p. 215.

37 A respeito da criação do Partido Verde no Brasil, não obstante a realidade atual da sigla tenha se alterado substancialmente nos últimos anos, distanciando-se da pauta ecológica que o caracterizou na época da sua criação em meados da Década de 1980, v. GABEIRA, Fernando et all. Partido Verde: propostas de ecologia política. Rio de Janeiro: Editora Anima, 1986. No ano de 2015, registra-se também a criação do Partido Rede Sustentabilidade, com a temática ecológica no seu programa político central, tendo, inclusive, Marina Silva, ExMinistra do Meio Ambiente, como uma de suas principais lideranças. 
nacional, estaduais e municipais) ${ }^{38}$ e oportunizar a manifestação do público interessado (ex. entidades ambientalistas, entidades científicas, etc.).

No campo da Administração Pública, há também inúmeros instrumentos administrativos catalisadores da participação pública em matéria ambiental. O paradigma democrático-participativo deve conduzir as práticas administrativas, abrindo espaço para a participação pública. Entre os instrumentos administrativos no campo ambiental que autorizam e potencializam a participação pública, destacam-se a publicação do estudo e do relatório de impacto ambiental (EIARIMA) no âmbito do licenciamento ambiental (art. 225, § $1^{\circ}$, IV, da CF/88, art. 9o, III, e art. 10, caput e $\S 1^{\circ}$, da Lei 6.938/81, Lei Complementar 140/2011 e Resoluções 01/86, 06/86 e 237/97 do CONAMA), inclusive com a previsão de realização de audiência pública (Resolução 09/87 do CONAMA), o direito de petição aos órgãos públicos reivindicando acesso à informação ambiental (art. 50, XXXIII, da CF/88, Lei 10.650/2003 e Lei 12.527/2011), a participação da sociedade civil nos órgãos colegiados ambientais (art. 39, IV e V, da Lei 9.433/97). A título de exemplo, no campo do acesso à informação ambiental (tema que retomaremos à frente) e participação pública na seara administrativa, o art. 11 da Resolução 01/86 do CONAMA dispõe que "respeitado o sigilo industrial, assim solicitado e demonstrado pelo interessado, o RIMA será acessível ao público. Suas cópias permanecerão à disposição dos interessados, nos centros de documentação ou bibliotecas da SEMA e do órgão estadual de controle ambiental correspondente, inclusive durante o período de análise técnica".

Também operando como instrumento viabilizador da participação pública em matéria ambiental, destaca-se a presença de representantes da comunidade, indicados livremente pelas associações civis, nos conselhos e órgãos colegiados de defesa do ambiente dotados de poderes normativos. Exemplo altamente significativo é o do Conselho Nacional do Meio Ambiente (CONAMA), o mais importante órgão colegiado de âmbito nacional, com competência, entre outras, de estabelecer normas, critérios e padrões relativos ao controle e à manutenção da qualidade do ambiente com vistas ao uso racional e sustentável dos recursos naturais, conforme dispõe o art. $8^{\circ}$, VII, da Lei 6.938/81. Portanto, a presença da sociedade civil organizada na composição do 38 No âmbito do Senado Federal, existe a Comissão de Meio Ambiente, Defesa do Consumidor e Fiscalização e Controle (CMA); ao passo que, na Câmara dos Deputados, tem-se a Comissão de Meio Ambiente e Desenvolvimento Sustentável (CMADS). 


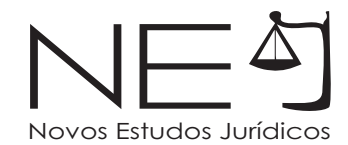

CONAMA constitui importante mecanismo de participação pública e de cooperação entre governo e sociedade, propiciando o debate de temas ambientais relevantes entre representantes da União, dos Estados e Municípios, da iniciativa privada e de organizações da sociedade civil. A atuação das entidades ambientalistas em tais órgãos colegiados permite, em certa medida, além do exercício de algum controle sobre as práticas administrativas, a participação na formulação e na execução de políticas públicas ambientais.

O direito à audiência pública nos procedimentos administrativos ambientais (e também judiciais, conforme veremos à frente) representa também importante dimensão dos direitos ambientais procedimentais, inclusive congregando tanto o direito à informação quanto o direito à participação pública na conformação da vontade estatal e tomada de decisão em matéria ambiental. Com relação à audiência pública, Vasco Pereira da Silva identifica o direito à audiência nos procedimentos administrativos de natureza ambiental como direito fundamental e fase obrigatória do procedimento administrativo, tendo como objetivo possibilitar uma tomada de decisão mais correta em face da globalidade dos interesses em jogo. ${ }^{39}$ Ainda segundo o autor português, o desrespeito do direito fundamental em questão implicaria a nulidade do procedimento administrativo. ${ }^{40}$ Ao analisar a legislação portuguesa sobre o tema (Código de Procedimento Administrativo), Luís F. Colaço Antunes destaca que "qualquer procedimento capaz de produzir rumores no ambiente deve ser, desde logo, levado ao conhecimento dos portadores do interesse difuso ambiental, garantindo, posteriormente, um adequado contraditório através da audiência dos interessados" ${ }^{41}$

O direito à audiência é projeção do caráter democrático-participativo da norma constitucional de tutela do ambiente (art. 225), já que o objetivo último da audiência, por exemplo, em procedimento de licenciamento ambiental (ou até mesmo no curso de uma ação civil pública, conforme veremos à frente), é assegurar o acesso à informação relativa à questão ambiental em causa, bem como possibilitar a intervenção das pessoas interessadas na tomada de decisão

$39 \quad$ PEREIRA DA SILVA, Verde cor de direito..., p. 152.

40 Idem, ibidem.

41 ANTUNES, Luís Filipe Colaço. Direito público do ambiente. Lisboa: Almedina, 2008, p. 90. Na doutrina brasileira, v. BIM, Eduardo Fortunato. Audiências públicas. São Paulo: Revista dos Tribunais, 2014, especialmente tratando das audiências públicas ambientais nas p. 179-205. 
e conformação da vontade estatal (do Estado-Administrador). ${ }^{42}$ De acordo com o art. $1^{\circ}$ da Resolução 09/87 do CONAMA, que dispõe especificamente sobre as audiências públicas ambientais, as mesmas têm "por finalidade expor aos interessados o conteúdo do produto em análise e do seu referido RIMA, dirimindo dúvidas e recolhendo dos presentes as críticas e sugestões a respeito". Segundo o art. $2^{\circ}$ do mesmo diploma, "sempre que julgar necessário, ou quando for solicitado por entidade civil, pelo Ministério Público, ou por cinquenta ou mais cidadãos, o órgão de meio ambiente promoverá a realização de audiência pública", bem como, de acordo com o $\S 1^{\circ}$ do mesmo dispositivo, que, com o recebimento do relatório de impacto ambiental (RIMA), o órgão público ambiental responsável publicará e anunciará pela imprensa local a abertura de prazo de 45 dias para a solicitação de audiência pública para a discussão do empreendimento. Também a Lei 9.784/99, que institui procedimento administrativo no âmbito federal, estabeleceu, no seu art. 32, a realização de audiência pública como parte do procedimento instrutório, o que também incide em procedimentos administrativos ambientais em termos gerais, não se limitando apenas ao âmbito do licenciamento. ${ }^{43}$

À luz dos exemplos citados, cabe pontuar que a aproximação entre a Administração Pública (em todos os planos federativos) e a sociedade civil é deveras salutar à proteção ecológica, estimulando práticas colaborativas e participativas. Afinal de contas, retomando a lição de Carla Amado Gomes, "a democracia participativa irradiou para a atividade administrativa, abrindo as portas do procedimento à intervenção dos interessados para defesa dos seus interesses e para a formação de consensos alargados em torno da noção de interesse público". ${ }^{44}$ Por fim, após destacar que a participação pública em matéria ambiental operada no âmbito de toda a esfera estatal, abarcando os três poderes republicanos (legislativo, administrativo e judiciário) em todos os planos federativos, registramos que a participação no âmbito do Poder Judiciário será objeto de análise em tópico à frente, quando tratarmos especificamente

42 O Superior Tribunal de Justiça já se pronunciou sobre a necessidade de realização de audiência pública no âmbito do licenciamento ambiental, inclusive por força do princípio da precaução: AgRg na SLS 1.552/BA, Corte Especial, Rel. Min. Ari Pargendler, j. 16.05.2012.

43 O art. 15 da Lei de Biossegurança (Lei 11.105/2005), prevê que "a CTNBio poderá realizar audiências públicas, garantida participação da sociedade civil, na forma do regulamento. Parágrafo único. Em casos de liberação comercial, audiência pública poderá ser requerida por partes interessadas, incluindo-se entre estas organizações da sociedade civil que comprovem interesse relacionado à matéria, na forma do regulamento".

GOMES, Carla Amado. A prevenção à prova no direito do ambiente. Coimbra: Coimbra Editora, 2000 , p. 63. 
do acesso à justiça no campo ecológico. A próxima "parada" do nosso estudo recairá sobre o acesso à informação ambiental.

\subsection{O ACESSO À INFORMAÇÃO AMBIENTAL: ENTRE DEVERES ESTATAIS, DEVERES FUNDAMENTAIS E DIREITOS FUNDAMENTAIS DOS CIDADÃOS}

"A Política Nacional do Meio Ambiente visará: (...) V - à difusão de tecnologias de manejo do meio ambiente, à divulgação de dados e informações ambientais e à formação de uma consciência pública sobre a necessidade de preservação da qualidade ambiental e do equilíbrio ecológico" (Art. 4º, V, da Lei 6.938/81).

O acesso à informação ambiental ${ }^{45}$ constitui componente essencial do exercício pleno da democracia participativa ecológica e, portanto, além de um dos pilares do princípio da participação pública, assume também a condição de direito fundamental, que, ademais de assegurado em caráter geral pelo artigo $5^{\circ}, \mathrm{XIV}$, da $\mathrm{CF} / 88$, apresenta uma dimensão particularmente relevante na esfera da proteção ambiental. Somente o cidadão devidamente informado e consciente da realidade e da problemática ambiental é capaz de atuar de forma qualificada no processo político, ensejando a autonomia e a autodeterminação da sua condição políticoparticipativa. $\mathrm{O}$ acesso à informação está diretamente relacionado à própria esfera de liberdade do indivíduo. Especialmente num mundo como o de hoje, em que a informação circula de forma desordenada e complexa, somente o acesso à informação possibilitará ao indivíduo e à coletividade (as entidades ambientalistas, movimentos populares, etc.) tomarem partido no jogo político ambiental.

No plano internacional, cabe destacar a consagração do direito de acesso à informação ambiental no Princípio 10 da Declaração do Rio de 1992 na Convenção de Aarhus (1998) e, mais recentemente, no Acordo Regional para América Latina e Caribe sobre os direitos ambientais procedimentais (2018). A Convenção de Aarhus, nesse sentido, elenca entre os seus objetivos o de garantir ao público em geral, bem como às organizações não governamentais, o acesso informação ambiental e a mecanismos judiciais eficazes para proteger os seus interesses legítimos, bem como a garantir a aplicação da lei em questões ambientais. De acordo com o

45 Sobre a temática da informação em matéria ambiental, v., por todos, MACHADO, Paulo Affonso Leme. Direito à informação e meio ambiente. São Paulo: Malheiros, 2006. 
teor literal da Convenção, o Estado, "além e sem prejuízo dos procedimentos de revisão referidos nos §§ $1 .^{\circ}$ e $2 .^{\circ}$ acima, assegurará aos membros da comunidade que satisfaçam os critérios estabelecidos no direito interno, o acesso aos processos administrativos ou judiciais destinados a impugnar os atos e as omissões de particulares e de autoridades públicas que infrinjam o disposto no respectivo direito interno em relação ao ambiente (art. $\left.9 .^{\circ}, 3\right)^{\prime \prime}$. Para ilustrar a evolução que verificamos em outros países e na esfera supranacional a respeito da temática, cabe referir a Diretiva 2003/4/EC, de 28 de janeiro de 2003, da Comunidade Europeia, assim como a Lei sobre o Regime de Livre Acesso à Informação Pública em Matéria Ambiental argentina (Lei n. 25.831, de 23 de novembro de 2003) e a Lei de Informação Ambiental alemã (Umweltinformationsgesetz - UIG) de $2004^{46}$.

A respeito da questão, Jonas Ebbesson destaca que a Corte Europeia de Direitos Humanos (Caso Guerra e Outros v. Itália, julgado em 19 de fevereiro de 1998) reconheceu, vinculando a temática do acesso à informação ambiental à proteção dos direitos humanos, a violação - por parte do Estado - do direito humano de respeito à privacidade e à vida familiar na hipótese em que o Estado falha ou se omite em providenciar informação essencial sobre atividades perigosas e permitir às pessoas conhecer e avaliar os riscos que elas e seus familiares poderiam correr. Tal entendimento da Corte reconheceu o "direito a saber (Rightto-Know) sobre questões ambientais". ${ }^{47}$ De acordo com Paulo A. Leme Machado, "a informação ambiental deve ser transmitida de forma a possibilitar tempo suficiente aos informados para analisarem a matéria e poderem agir diante da Administração Pública e do Poder Judiciário. A informação ambiental deve ser prevista nas convenções internacionais de forma a atingir não somente as pessoas do país onde se produza o dano ao ambiente, como também atingir as pessoas de países vizinhos que possam sofrer as consequências do dano ambiental". ${ }^{48}$

O constituinte brasileiro de 1988 mostrou-se preocupado com a questão do acesso à informação de um modo geral, ao consagrar duas garantias individuais: primeiramente, como já destacamos, mediante a norma contida no inciso XIV do art. $5^{\circ}$ da CF/88, ao estabelecer que "é assegurado a todos o acesso à informação

46 Na doutrina alemã, a respeito da Umweltinformationsgesetz - UIG, v. ERBGUTH, Wilfried; SCHLACKE, Sabine. Umweltrecht. 5.ed. Baden-Baden: Nomos, 2014, p. 123-130.

47 EBBESSON, Public participation..., p. 699.

48 MACHADO, Direito ambiental brasileiro..., p. 127. 
e resguardado o sigilo da fonte, quando necessário ao exercício profissional". Soma-se a tal garantia a previsão contida no inciso XXXIV do mesmo dispositivo constitucional, dispondo que "são a todos assegurados, independentemente de taxas: a) o direito de petição aos poderes públicos em defesa de direito ou contra ilegalidade ou abuso de poder, e b) a obtenção de certidões em repartições públicas, para a defesa de direitos e esclarecimento de situações de interesse pessoal". Os dispositivos citados, conforme veremos logo à frente, foram regulamentados no plano infraconstitucional pela Lei de Acesso à Informação (Lei 12.527/2011). Especificamente em relação à informação ambiental, podemos destacar o art. 225, § 10, que estabelece o dever do Poder Público, como forma de assegurar efetividade do direito fundamental ao ambiente: "exigir, na forma da lei, para a instalação de obra ou atividade potencialmente causadora de significativa degradação do meio ambiente, estudo prévio de impacto ambiental, a que se dará publicidade" (inciso IV); e "promover a educação ambiental em todos os níveis de ensino e a conscientização pública para a preservação do meio ambiente" (inciso VI), posteriormente regulamentados no plano infraconstitucional, conforme veremos na sequência.

O marco delineado pela CF/88, conforme destacamos no parágrafo antecedente, atribui deveres ao Estado que repercutem na esfera da informação ambiental, assumindo a condição de verdadeiros deveres estatais de informação ambiental. A respeito da questão, destacamos o entendimento de Alexandre Kiss e Dinah Shelton no sentido da existência, no plano internacional, de um dever de informar e consultar atribuído ao Estado, no tocante a questões ambientais. De acordo com os autores, "um Estado que pretenda empreender ou autorizar atividades capazes de ocasionar um impacto significativo sobre o meio ambiente de outro Estado deve informar o este último e transmitir os detalhes pertinentes sobre o projeto". ${ }^{49}$ Os deveres estatais em questão encontram-se reconhecidos no Princípio 19 da Declaração do Rio (1992), ao declarar que "os Estados fornecerão, oportunamente, aos Estados potencialmente afetados, notificação prévia e informações relevantes acerca de atividades que possam vir a ter considerável impacto transfronteiriço negativo sobre o meio ambiente, e se consultarão com estes tão logo seja possível e de boa fé".

49 KISS; SHELTON, Guide to international environmental law..., p. 100-101. 
Os mesmos deveres estatais de informação consagrados no dispositivo citado também encontram incidência no plano doméstico dos Estados-Nação e tem como beneficiários a coletividade em geral, indivíduos, entidades ambientalistas, etc. No Brasil, a Lei de Acesso à Informação Ambiental (Lei 10.650/2003) é o melhor exemplo disso, pois objetiva assegurar acessível para o público em geral os dados e as informações existentes no âmbito nos órgãos e entidades integrantes do Sistema Nacional do Meio Ambiente (SISNAMA), tal como previstos na Lei 6.938/81 (art. 6). Ainda no plano da legislação infraconstitucional, também expressam esse dever de informação a cargo do Estado a exigência de publicização do estudo de impacto ambiental e do relatório de impacto ambiental (EIA-RIMA), previsto na Lei 6.938/81 (art. 10, § $1^{\circ}$ ) e na CF/88 (art. 225, § $\left.1^{\circ}, \mathrm{IV}\right)^{50}$, bem como na condição de instrumentos da Política Nacional do Meio Ambiente, a criação do Sistema Nacional de Informações sobre o Meio Ambiente (art. 9, VII, da Lei 6.938/81) e a instituição do Relatório de Qualidade do Meio Ambiente, a ser divulgado anualmente pelo IBAMA (art. $9^{\circ}, \mathrm{X}$, da Lei 6.938/81).

Com o mesmo propósito de assegurar acesso à informação de natureza ambiental, o art. 50, VI, da Política Nacional de Recursos Hídricos (Lei 9.433/97), estabeleceu, como instrumento da PNRH, a criação do Sistema de Informação sobre Recursos Hídricos. Outro exemplo peculiar a respeito da informação ambiental é a situação prevista no art. 40 da Lei de Biossegurança (Lei 11.105/2005), ao determinar que "os alimentos e ingredientes destinados ao consumo humano ou animal que contenham ou sejam produzidos a partir de organismos geneticamente modificados ou derivados deverão conter informação neste sentido em seus rótulos, conforme regulamento". A recente Lei da Política de Educação para o Consumo Sustentável (Lei 13.186/2015) também dispôs sobre o acesso à informação ambiental, consagrando, entre os objetivos da referida política pública, previstos no art. $2^{a}$ do diploma, "zelar pelo direito à informação e pelo fomento à rotulagem ambiental (inciso VIII)" e "incentivar a certificação ambiental (inciso IX)", bem como no seu art. $3^{\circ}$, I, que incumbe ao poder público, em âmbito federal, estadual e municipal, "promover campanhas em prol do consumo sustentável, em espaço nobre dos meios de comunicação de massa".

50 "Art. $225(\ldots) \S 1^{\circ}(\ldots)$ IV - exigir, na forma da lei, para instalação de obra ou atividade potencialmente causadora de significativa degradação do meio ambiente, estudo prévio de impacto ambiental, a que se dará publicidade". 
A realização de audiência pública, nessa perspectiva, também se apresenta como mecanismo exemplar para conferir não apenas espaço para a participação pública na tomada de decisão, como já referido em tópico precedente, mas também para franquear acesso à informação aos interessados sobre o estudo de impacto ambiental levado a cabo em face da instalação de obra ou atividade causadora ou potencialmente causadora de significativa degradação ambiental. Nesse sentido, Álvaro Valery Mirra afirma que a audiência pública garantida constitucionalmente por força das normas do art. $1^{\circ}$, parágrafo único, da CF/88, que estabeleceu no país o regime de democracia semidireta, e do art. 225, caput, que consagrou o direito de todos ao meio ambiente ecologicamente equilibrado, é um instrumento de informação e consulta da população a respeito de uma atividade sujeita ao estudo de impacto ambiental, aparecendo, assim, como um dos principais instrumentos de participação popular na proteção do meio ambiente. ${ }^{51}$ De acordo com Colaço Antunes, "a participação do público, com base numa correta informação, configura-se como um dos elementos básicos do procedimento de avaliação de impacto ambiental. O estudo de impacto ambiental deve submeter-se a informação pública juntamente com o resto das peças documentais do dossier". ${ }^{2}$

Ainda nesse contexto, merece destaque a Lei do Acesso à Informação (Lei 12.527/2011), que representou um marco extremamente significativo na edificação de um sistema público de acesso à informação com forte índole democráticoparticipativa. De modo complementar à Lei de Acesso à Informação Ambiental (Lei 10.650/2003), a Lei 12.527/2011 regulamenta, no plano infraconstitucional, o inciso XXXIII do art. $5^{\circ}$, o inciso II do $\S 3^{\circ}$ do art. 37 e o $\S 2^{\circ}$ do art. 216 da CF/88. Alinhada com esse cenário normativo-constitucional, a Lei 12.527/2011 estabelece, no seu art. $1^{\circ}$, parágrafo primeiro, que "subordinam-se ao regime desta Lei: I - os órgãos públicos integrantes da administração direta dos Poderes Executivo, Legislativo, incluindo as Cortes de Contas, e Judiciário e do Ministério Público; II - as autarquias, as fundações públicas, as empresas públicas, as sociedades de economia mista e demais entidades controladas direta ou indiretamente pela União, Estados, Distrito

51 MIRRA, Álvaro Luiz Valery. Impacto ambiental: aspectos da legislação brasileira. 2.ed. São Paulo: Editora Juarez de Oliveira, 2002, 81.

52 ANTUNES, Luís Felipe Colaço. O procedimento administrativo de avaliação de impacto ambiental: para uma tutela preventiva do ambiente. Coimbra: Almedina, 1998, p. 691-692. 
Federal e Municípios". A partir da vigência da nova legislação, nenhuma entidade pública está imune ao dever de assegurar o acesso à informação por ela detida. O que coloca a questão ambiental em contato direto com tal diploma normativo é o fato de a proteção do ambiente transportar sempre a natureza de interesse público (interesse público primário). Portanto, qualquer informação ambiental de posse de entidade pública passa a ser acionável com amparo na 12.527/2011, considerando-se, por exemplo, a sua extrema relevância para a atuação das entidades ambientalistas (ou mesmo do cidadão) na hipótese de situação de lesão ou ameaça de lesão ao bem jurídico ambiental.

Ainda que cuidemos aqui de princípio e dever autônomo (conforme previsto no artigo 37, caput, CF/88), o princípio da publicidade (e o dever estatal de conferir publicidade aos atos administrativos) também agrega força normativa ao princípio democrático-participativo e, de outra parte, opera como garantia do próprio direito e correspondente dever de acesso à informação pública em termos gerais. Com efeito, o princípio da publicidade impõe limites à atuação do Estado-Administrador, em vista principalmente da possibilidade do controle social que deve pautar a sua atividade num Estado Democrático de Direito, tal como enunciado no art. $1^{\circ}$, caput, da CF/88. A publicidade assegura, ademais, a devida transparência na condução da administração pública, possibilitando a todos os interessados tomarem ciência de temas que lhes tocam diretamente e que dizem com o exercício e a proteção de seus direitos, inclusive e de modo particularmente relevante quando se cuida de dar efetividade ao (direito de) acesso à informação ambiental. Nesses termos, Paulo Afonso Leme Machado destaca que a publicidade "abre as portas da Administração Pública", assim como "a transparência conserva essas portas abertas e mantém a circulação da informação pelas referidas portas". De modo complementar, destaca o autor que a publicidade estrutura o manuseio da informação, ao passo que a transparência operacionaliza a fruição do direito à informação frente à Administração Pública e àqueles que usam bens comuns da coletividade. ${ }^{53}$

Além disso, há que se ter sempre em consideração a desigualdade fática e vulnerabilidade (técnica, econômica, jurídica, etc.) do cidadão tanto em face dos poderes econômicos privados quanto do Poder Público, nem sempre, 53 MACHADO, Direito à informação e meio ambiente..., p. 62. 


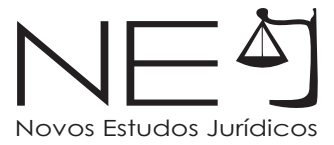

convém frisar, isento em relação aos interesses econômicos dominantes. O acesso à informação, nesse plano, atua como mecanismo de equalização das relações jurídicas, possibilitando ao cidadão, de forma individual ou coletiva (por exemplo, por meio de organizações não governamentais ambientais), reivindicar, em um patamar mais igualitário, o respeito ao seu direito fundamental ao ambiente. Afinal de contas, a defesa ecológica (e os valores morais e jurídicos que lhe dão fundamento) representa a defesa da própria sociedade e dos valores constitucionais que informam a nossa comunidade política. A título ilustrativo, no tocante ao direito à informação no Código de Defesa do Consumidor e tomando por base o diálogo de fontes normativas entre o Direito do Consumidor e o Direito Ambiental, é importante destacar a consagração do direito à informação nesse contexto. No diploma referido, é possível identificar de forma paradigmática a ideia de "vulnerabilidade" do destinatário da informação, ao prever que o direito básico à informação titularizado pelo consumidor em geral, previsto do inciso III do caput do art. $6^{\circ}$, de modo que "a informação adequada e clara sobre os diferentes produtos e serviços, com especificação correta de quantidade, características, composição, qualidade, tributos incidentes e preço, bem como sobre os riscos que apresentem".

Outra questão de alta relevância diz com a assim chamada eficácia do direito à informação (e de modo geral dos direitos fundamentais) na esfera das relações entre particulares ${ }^{54}$. Dito de outro modo, é necessário responder se os atores privados (e não apenas os entes públicos) também estão obrigados a fornecer informações que detenham em seu poder, quando tais informações sejam essenciais a informar grupos sociais ou mesmo indivíduos a respeito de questões relevantes atinentes à proteção do ambiente. Uma resposta afirmativa, ainda que carente de maior desenvolvimento quanto ao seu detalhamento, já é possível anunciar a partir do reconhecimento de uma eficácia entre particulares (ou horizontal) do direito fundamental ao ambiente ${ }^{55}$, implicando, por exemplo, o dever de informação ambiental dos particulares e, conforme veremos mais

\footnotetext{
54 Sobre o problema em termos gerais, v. as diversas contribuições contidas na obra coletiva organizada por SARLET, Ingo Wolfgang (Org.). Constituição, direitos fundamentais e direito privado. 3.ed. Porto Alegre: Livraria do Advogado, 2011.

55 No tocante à eficácia do direito fundamental ao ambiente nas relações entre particulares, v. FENSTERSEIFER, Direitos fundamentais e proteção do ambiente..., p. 245-258; e BELLO FILHO, Ney de Barros. Direito ao ambiente: da compreensão dogmática do direito fundamental na pós-modernidade. Porto Alegre: Livraria do Advogado, 2012, p. 68-73.
} 
adiante, a possibilidade de inversão do ônus da prova nos processos judiciais e administrativos que versem sobre a tutela ecológica. ${ }^{56}$ Como fundamento legislativo (ainda que não criem obrigações expressas de informação) dos deveres de informação ambiental na esfera do ordenamento jurídico privado. é possível invocar o princípio da boa-fé objetiva (art. 422 do CC/2002), o princípio da função social e ecológica da propriedade (art. 1.228, $\S 1^{\circ}$, do CC/2002), o princípio da função social do contrato (art. 421 do CC/2002) e o princípio da função social da empresa, bem como do instituto do abuso de direito (art. 187 do CC/2002), todos reguladores das relações jurídicas de direito privado e que, ademais, dão concretude aos princípios, aos direitos e aos deveres de matriz constitucional colacionados anteriormente.

Os institutos jurídicos citados atuam no sentido de determinar deveres conexos a direitos em geral, fazendo com que o exercício de determinado direito esteja alinhado ao seu fim social, especialmente relevante quando estiver em causa direito de natureza fundamental, como é o caso do direito ao ambiente. Aqui manifestamos como particularmente relevante a relação entre a inversão do ônus da prova e o acesso à informação ambiental, uma vez que, à luz dos princípios da prevenção e da precaução, deve-se exigir do suposto poluidor (empreendedor de prática ou atividade lesiva ou potencialmente lesiva ao ambiente) que forneça as informações (estudos, laudos, etc.) o qual detém em seu poder, inclusive com o propósito de demonstrar a segurança e as consequências em termos ecológicos do empreendimento. Isso, por sua vez, é aplicado tanto no âmbito administrativo quanto judicial, recaindo esse dever (e a correspondente inversão do ônus probatório) sobre quem pretenda desenvolver uma determinada atividade cuja lesividade para o ambiente já seja conhecida, bem como quando não esteja cientificamente comprovada. ${ }^{57}$ Ademais, no âmbito das relações privadas, também operamos a proteção dos indivíduos e grupos vulneráveis, colocando-se, entre eles, inclusive as futuras gerações, conforme a lição de Claudia Lima Marques e Bruno Miragem. ${ }^{58}$ Portanto, o acesso à informação em

56 O Supremo Tribunal Federal já acolheu, na sua jurisprudência, a eficácia dos direitos fundamentais nas relações entre particulares no julgamento do leading case do Recurso Extraordinário n. 201.819/RJ: STF, RE 201.819/RJ, $2^{\mathrm{a}}$ Turma, Rel. Min. Ellen Gracie (Rel. p/ Acórdão: Min. Gilmar Mendes), j. 11.10.2005.

57 Sobre o tema, v. GOMES, A prevenção à prova..., p. 35-39.

58 MARQUES, Cláudia Lima; MIRAGEM, Bruno. O novo direito privado e a proteção dos vulneráveis. São Paulo: Revista dos Tribunais, 2012, p. 166 e ss. Na doutrina alemã, defendendo o mesmo entendimento, v. HIPPEL, Eike von. Der Schutz des Schwächeren. Tübingen: J.C.B.Mooh, 1982, p. 140 e ss. 
poder de particulares, quando imprescindível para apurar a existência ou mesmo potencial ocorrência de dano ambiental, deve ser vislumbrada, a depender por óbvio da situação concreta, como mecanismo de equalização de forças privadas e, ao mesmo tempo, como instrumento para a proteção de grupos sociais vulneráveis (neles incluídas as futuras gerações), aqui não apenas na perspectiva ambiental em sentido estrito. A inversão do ônus probatório em ações judiciais, conforme já mencionamos e desenvolveremos no tópico subsequente sobre o acesso à justiça em matéria ambiental ilustra bem a posição por nós defendida.

Por fim, é importante reiterar a relevância do Poder Judiciário - que, de resto, encontra-se igualmente vinculado pelo dever de proteção ambiental no sentido de assegurar o cumprimento, por parte do Estado e de particulares (com destaque para atores detentores de poder social e econômico), dos seus respectivos deveres de informação ambiental, bem como de parte dos titulares do direito ao ambiente (ou seja, toda a coletividade), salvaguardar o direito à informação ambiental. Para superar eventuais óbices criados, tanto por agentes públicos quando privados, no tocante ao acesso à informação ambiental (e até mesmo em relação à sua divulgação), torna-se perfeitamente passível a sua reivindicação judicial (a título de exemplo, em se tratando de agente público, a negativa do acesso à informação pode ser combatida judicialmente por meio do ajuizamento de mandado de segurança, tanto individual quanto coletivo, a depender das circunstâncias). ${ }^{59}$ Há, portanto, a possibilidade de acionamento do Poder Judiciário para a obtenção de acesso à informação ambiental, haja vista que estará sempre em causa interesse público. Tecidas essas considerações finais a respeito da relevância dos Juízes e Tribunais para salvaguardar o acesso à informação ambiental, ingressaremos, a partir de agora, na temática do acesso à justiça em matéria ambiental.

\subsection{O ACESSO À JUSTIÇA EM MATÉRIA AMBIENTAL}

O acesso à justiça, no âmbito dos direitos ambientais procedimentais, é aquele que detém o desenvolvimento mais recente, na medida em que, tanto 59 O direito à informação tem sido tratado pela jurisprudência do STJ, especialmente em matéria envolvendo relações de consumo, inclusive como dever positivo ou prestacional a cargo do fornecedor de produtos e serviços: STJ, REsp 586.316/MG, 2a Turma, Rel. Min. Herman Benjamin, j. 17.04.2007. 
o acesso à informação ambiental quanto a participação pública na tomada de decisão já possuíam mecanismos normativos mais desenvolvidos até mesmo antes da Convenção de Aarhus (1998) ${ }^{60} \mathrm{O}$ acesso à justiça, é importante destacar, não é sinônimo de acesso ao Poder Judiciário. Trata-se de conceito mais amplo, tanto que o Princípio 10 da Declaração do Rio (1992) fez questão de deixar isso claro, ao dispor que será assegurado "acesso efetivo a mecanismos judiciais e administrativos". Quando trata dos mecanismos administrativos, o dispositivo em questão abre o seu leque normativo para além do espectro judicial. De certa forma, o acesso à justiça em questões ambientais cumpre um papel que podemos denominar de "subsidiário", pois somente quando a "participação pública bem informada" não tiver força suficiente para afastar situações de lesão ou ameaça de lesão ao bem jurídico ambiental no âmbito "extrajudicial" é que a via "judicial" deverá ser acionada para corrigir essa situação ou mesmo para fazer valer os demais direitos ambientais procedimentais (no caso, o acesso à informação e a participação pública na tomada de decisão).

A conexão entre direitos fundamentais e procedimentos processuais, como pontua Robert Alexy, objetiva unir o aspecto material e o aspecto procedimental num modelo que garanta o primado do direito material ${ }^{61}$, o que deve ser a tônica no acesso à justiça em matéria ambiental. $\mathrm{O}$ direto ao procedimento, judicial e administrativo, opera como projeção do próprio direito material, já que busca conferir ao mesmo uma tutela integral na busca pela sua efetividade. De tal sorte, conforme já tratamos anteriormente, reconhecemos a dimensão procedimental (ou processual) como essencial para contemplar um sistema de tutela efetiva do direito fundamental ao ambiente, inclusive assegurando, como sustenta Patryck de Araújo Ayala, um devido processo ambiental ${ }^{62}$, o qual deverá ser necessariamente participativo. Cabe ao processo civil, nesse sentido, criar técnicas capazes de dar conta de uma tutela adequada e efetiva dos direitos, especialmente dos direitos fundamentais, sem nunca perder de vista a sua natureza de instrumento e o primado do direito material.

60 KRÄMER, Ludwig. "The Aarhus Convention and EU law". In: A Trilogia de Aarhus. GOMES, Carla Amado; ANTUNES, Tiago (Coords.). Lisboa: Instituto de Ciências Jurídico Políticas/ Universidade de Lisboa, $2015, \mathrm{p}$. 3-4. Disponível em: http://icjp.pt/sites/default/files/publicacoes/ files/ebook_trilogia_aarhus.pdf. Acesso em: 27 de março de 2017.

61 ALEXY, Teoria dos direitos fundamentais..., p. 473-474.

62 AYALA, Patryck de Araújo. Devido processo ambiental e o direito fundamental ao ambiente. Rio de Janeiro: Lumen Juris, 2011, especialmente p. 325 e ss. 


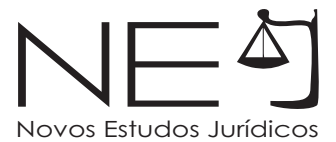

O acesso à justiça, de acordo com Jonas Ebbesson, é um elemento essencial da participação pública, como instrumento para aplicação da legislação ambiental, correção de decisões administrativas errôneas e enquadrar as autoridades competentes no seu devido papel. ${ }^{63}$ É nesse mesmo sentido a lição de Luiz G. Marinoni que, amparado numa leitura do Direito Processo Civil com base na Teoria dos Direitos Fundamentais, afirma que a participação por meio da ação judicial justifica-se também numa perspectiva democrática, já que essa "não mais se funda ou pode se fundar o sistema representativo tradicional". ${ }^{64}$ As ações judiciais conformam, em alguma medida, o direito à participação inerente aos direitos fundamentais, permitindo a democratização do poder por intermédio da participação popular, que, conforme pontua Marinoni, se dá, no caso da ação judicial, de forma direta. ${ }^{65} \mathrm{Em}$ sintonia com tal entendimento, Antônio $\mathrm{H}$. Benjamin refere que, como benefício substantivo da "constitucionalização" da proteção do ambiente, deve-se "ampliar os canais de participação pública, sejam os administrativos, sejam os judiciais", com o afrouxamento do formalismo individualista especialmente para os procedimentos judiciais, que é a marca da legitimação para agir tradicional. ${ }^{66}$

A respeito do tema, Carla Amado Gomes atribui natureza instrumental ao acesso à justiça em vista dos direitos de acesso à informação e de participação pública na tomada de decisão, na medida em que permite ultrapassar restrições indevidas ao exercício de tais direitos. Segundo a autora, o acesso à justiça serviria como mecanismo de salvaguarda para a hipótese de violação aos demais direitos ambientais procedimentais. ${ }^{67}$ Não é diferente, em linhas gerais, o entendimento de Luís F. Colaço Antunes, para quem "a tutela procedimental é a antecâmara da tutela processual do interesse difuso ambiental". ${ }^{68}$ Ou seja, a via judicial só passa a ser legitimada se a instância administrativa não for capaz de assegurar

$63 \quad$ EBBESSON, Public participation..., p. 701.

64 MARINONI, Teoria geral do processo..., p. 196.

65 Idem, p. 198.

66 BENJAMIN, Antonio Herman. "Constitucionalização do ambiente e ecologização da Constituição brasileira". In: CANOTILHO, José Joaquim Gomes; MORATO LEITE, José Rubens (Orgs.). Direito constitucional ambiental brasileiro. São Paulo: Saraiva, 2007, p. 76.

67 GOMES, Carla Amado. "Legitimidade processual popular, litispendência e caso julgado". In: A Trilogia de Aarhus. GOMES, Carla Amado; ANTUNES, Tiago (Coords.). Lisboa: Instituto de Ciências Jurídico Políticas/ Universidade de Lisboa, 2015, p. 78. Disponível em: http://icjp.pt/sites/default/files/publicacoes/files/ebook_trilogia_aarhus.pdf. Acesso em: 27 de março de 2017.

ANTUNES, Direito público do ambiente..., p. 91. 
o devido exercício dos direitos ambientais procedimentais (e, numa perspectiva mais ampla, a proteção ao direito fundamental ao ambiente), tanto no âmbito do acesso à informação quanto da participação na tomada de decisão. Esse raciocínio está de acordo com certa tendência contemporânea verificada no cenário jurídico brasileiro, com o propósito de priorizar a resolução extrajudicial dos conflitos, como resultou evidenciado recentemente por meio do NCPC (art. $1^{\circ}$, § $2^{\circ}$ e $\S 3^{\circ}$, da Lei 13.105/2015). A utilização do Poder Judiciário para solucionar conflitos ambientais (em especial no tocante ao manuseio dos instrumentos processuais coletivos) deve ser utilizada apenas como última salvaguarda, ou seja, somente quando as demais instâncias tenham fracassado na tutela ecológica.

Tanto no plano judicial quanto extrajudicial devemos assegurar o caráter democrático-participativo da norma constitucional-ambiental, possibilitando aos atores sociais (associações ambientalistas, cidadãos, associações de bairro, movimentos populares, entidades científicas, etc.) uma participação qualificada (e, portanto, necessariamente bem informada) e ativa na formação da vontade e da tomada de decisão do Estado-Juiz, especialmente em ações de natureza coletiva, dado o impacto e a repercussão social das mesmas. No ordenamento jurídico brasileiro, há inúmeros instrumentos processuais que potencializam e podem ser utilizados com esse viés participativo-ambiental. Até mesmo as ações que tutelam direitos de vizinhança, em alguma medida, permitem ao cidadão, de forma individual, promover a tutela ecológica ${ }^{69}$ e foram, de certa forma, o embrião das ações processuais voltadas à tutela ecológica consagradas na legislação processual posteriormente. Nesse sentido, as duas principais ações processuais que tradicionalmente veiculam a proteção do ambiente são a ação civil púbica (Lei 7.347/85) e a ação popular (art. 50, LXXIII, da CF/88 e Lei 4.717/65).

Mas há inúmeros outros instrumentos processuais que também podem ser acionados para omesmo propósitoa dependerdaspeculiaridades docaso concreto. Esse é o caso do mandado de segurança individual e coletivo (art. $5^{\circ}$, LXIX e LXX, da CF/88) das ações voltadas ao controle concentrado de constitucionalidade, como a ação direta de inconstitucionalidade - ADI e a ação declaratória de constitucionalidade - ADC (Lei 9.868/99), do mandado de injunção (art. 5. LXXI, 69 PURVIN DE FIGUEIREDO, Guilherme José. A propriedade no direito ambiental. 3.ed. São Paulo: Revista dos

Tribunais, 2008, p. 107 e ss. 
da CF/88, e Lei 13.300/2016), da ação direta de inconstitucionalidade por omissão (art. 103, § 20 , da CF/88 e Lei 9.898/99) e da arguição de descumprimento de preceito fundamental - ADPF (Lei 9.882/99). Mais recentemente, registramos a crescente utilização de instrumentos participativos no campo judicial como a audiência pública judicial e o instituto do amicus curiae (art. $7^{\circ}$, § $2^{\circ}$, da Lei 9.868/99 e art. 138 do NCPC). No caso das audiências públicas judiciais, registramos o protagonismo do STF, tendo realizado já inúmeras audiências que versaram sobre a temática ecológica, oportunizando a participação de inúmeros atores (entidades ambientalistas, entidades científicas, etc.).

Estabelecido um panorama geral sobre o tema do acesso à justiça em matéria ambiental, o nosso propósito agora é analisar de forma específica a questão à luz de alguns exemplos que, a nosso ver, conformam manifestações dos direitos ambientais procedimentais, iniciando-se pela questão da legitimidade para a propositura de ações coletivas ambientais.

\subsubsection{ACESSO À JUSTIÇA E AMPLIAÇÃO DA LEGITIMIDADE PARA A PROPOSITURA DE AÇÕES COLETIVAS AMBIENTAIS}

O alargamento do acesso ao Poder Judiciário, alinhado com as garantias constitucionais da assistência jurídica integral e gratuita (art. $5^{\circ}$, LXXIV) e da inafastabilidade do controle jurisdicional (art. $5^{\circ}, \mathrm{XXXV}$ ), toma o rumo traçado pelo espírito democrático-participativo da CF/88. Essa "abertura de portas", ampliando, em especial, o acesso das pessoas necessitadas e dos grupos sociais vulneráveis (incluído aí até mesmo as futuras gerações) que antes não ingressavam nas nossas Cortes de Justiça por impossibilidade econômica e técnica, está diretamente relacionada à legitimidade para a propositura de ações judiciais, além, é claro, de outras questões estruturais e organizacionais do nosso Sistema de Justiça. A partir do enfoque da instrumentalidade do processo, Cândido Rangel Dinamarco defende a modificação do sistema processual de modo a torná-lo aberto ao maior número possível de pessoas. De acordo com o paradigma instrumentalista, o sistema processual deve adotar técnicas capazes de "dotar o processo de maior carga de utilidade social e política". ${ }^{70}$ Por meio de instrumentos como a ação civil pública, conforme pontua o autor, ampliamos a via de admissão em juízo 70 DINAMARCO, Cândido Rangel. A instrumentalidade do processo. 13.ed. São Paulo: Malheiros, 2008 , p. 362. 
e, consequentemente, o acesso à justiça, permitindo a abertura do sistema, de modo a proporcionar benefícios a indivíduos e grupos sociais. ${ }^{71}$

Contextualizados nesse cenário jurídico-processual, os direitos ambientais procedimentais, como direitos de acesso ou direitos de participação, estão atrelados à dimensão ou perspectiva procedimental do direito fundamental ao ambiente, na linha do que já tratamos anteriormente. Os procedimentos e os instrumentos administrativos e judiciais de que dispõem os titulares do direito fundamental ao ambiente (toda a coletividade, nos termos do caput do art. 225 da CF/88) são cruciais para assegurar a efetivação da legislação ambiental e salvaguardar o direito em si na hipótese de sua violação ou ameaça de violação, considerando-se que a defesa de tais direitos pode ser exercida por meio dos entes públicos autônomos encarregados de salvaguardar o interesse da coletividade e de grupos sociais vulneráveis (no caso, respectivamente, o Ministério Público e a Defensoria Pública), bem como por agentes privados (indivíduos, organizações não governamentais de defesa ecológica, movimentos populares, etc.) legitimados pela legislação processual para promover a tutela e a promoção do direito fundamental a viver em um ambiente sadio, equilibrado e seguro.

Dito isso, a ampliação da legitimidade para a propositura de ações judiciais, especialmente daquelas que veiculam a tutela de direitos difusos e coletivos, como é o caso da ação civil pública, está em sintonia com a concretização do princípio democrático e da garantia do acesso à justiça. Como assevera Marinoni, "quanto mais se alarga a legitimidade para a propositura dessas ações, mais se intensifica a participação do cidadão - ainda que representado por entidades - e dos grupos no poder e na vida social". ${ }^{72}$ Seguindo a mesma leitura constitucionalprocessual, o Ministro Herman Benjamin defende o entendimento de que, em alguns casos, conforme a dicção utilizada pelo legislador constitucional, "essa legitimação ampliada pode vir a ser automaticamente aceita pelo Poder Judiciário, sem necessidade de intervenção legislativa"73. Também Marcelo Abelha Rodrigues assinala que "quanto mais se abrirem portas de acesso, mais se terão a proteção e a efetivação deste direito sagrado a todos os seres que habitam

72 MARINONI, “Teoria geral do processo...”, p. 199.

73 Idem, p. 76. 


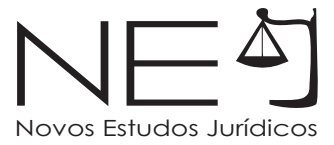

este Planeta. Por isso, toda interpretação a ser feita em relação à utilização das técnicas ambientais relativas ao acesso à justiça, especialmente as relacionadas com o poder de agir e de requerer a tutela jurisdicional ao longo da cadeia processual, deve ser vista sob o postulado de que, nas lides ambientais, o acesso à justiça deve ser alargado e jamais restringido". ${ }^{74}$

Com base em tais considerações, de forma a romper com uma concepção democrática tradicional, espelhada basicamente em uma abordagem representativa e indireta, devemos estimular a abertura cada vez maior das portas do Poder Judiciário e o reconhecimento de tal poder como instância estatal legitimada constitucionalmente a atuar na proteção dos direitos fundamentais e, portanto, do direito fundamental ao ambiente. A atuação judicial crescente no campo ecológico, somada à ampliação do rol de entes legitimados para a propositura de ações coletivas ambientais, tem encontrado guarida no Poder Judiciário e transformado tal poder em importante "arena" de luta pelos direitos ecológicos. De tal sorte, tanto individualmente (por meio de ações que tutelam direitos de vizinhança ou mesmo de ação popular) quanto por meio de entidades coletivas (associações civis, Ordem dos Advogados do Brasil, ${ }^{75}$ etc.) ou mesmo estatais (Ministério Público, Defensoria Pública ${ }^{76}$, IBAMA $^{77}$, etc.), o ajuizamento de ações ambientais deve ser tido como uma legítima forma de atuação em defesa da ordem constitucional e do direito fundamental ao ambiente.

\subsubsection{AÇÃO POPULAR AMBIENTAL E LEGITIMIDADE DO CIDADÃO PARA A DEFESA ECOLÓGICA}

A ação popular, nesse contexto processual-participativo, é um dos instrumentos processuais com maior amplitude democrática. Diferentemente de outros instrumentos, notadamente no âmbito do processo civil coletivo (como se verifica na hipótese da ação civil pública), a legitimidade para a propositura da

74 RODRIGUES, Marcelo Abelha. Processo civil ambiental. São Paulo: Revista dos Tribunais, 2008, p. 73.

75 Em decisão do STJ, resultou consagrada a legitimidade de Conselho Seccional da OAB para propor ação civil pública: STJ, REsp 1.351.760/PE, $2^{\mathrm{a}}$ Turma, Rel. Min. Humberto Martins, j. 26.11.2013.

76 No que tange à legitimidade da Defensoria Pública para a propositura de ação civil pública, registramos a recente decisão do STF: ADI 3.943/DF, Tribunal Pleno, Rel. Min. Cármen Lúcia, j. 07.05.2015. No campo doutrinário, v. FENSTERSEIFER, Tiago. Defensoria Pública, direitos fundamentais e ação civil pública. São Paulo: Saraiva, 2015.

77 A legitimidade do IBAMA para propor ação civil pública resultou reconhecida pelo STJ: REsp 789.640/PB, $2^{\text {a }}$ Turma, Rel. Min. Mauro Campbell Marques, j. 27.10.2009. 
ação popular é conferida ao cidadão, o que, do ponto de vista subjetivo, configura-se a partir da sua condição político-jurídica de eleitor. Não há, portanto, a necessidade de "mediação", ou seja, substituição processual por parte de outras entidades (por exemplo, do Ministério Público ou da Defensoria Pública), para a propositura da referida ação. Aí (e no seu objeto) reside o seu caráter altamente democrático-participativo. A ação popular foi consagrada no ordenamento jurídico brasileiro por meio da Lei 4.717/65.

No entanto, a ampliação do seu objeto para abarcar outros bens jurídico, como a proteção ambiental, antes circunscrito à proteção do erário público, somente ocorreu com a edição da CF/88. ${ }^{78}$ Dispõe o art. $5^{\circ}$ da CF/88, LXXIII, que "qualquer cidadão é parte legítima para propor ação popular que vise a anular ato lesivo ao patrimônio público ou de entidade de que o Estado participe, à moralidade administrativa, ao meio ambiente e ao patrimônio histórico e cultural, ficando o autor, salvo comprovada má-fé, isento de custas judiciais e do ônus da sucumbência". Há, nesse sentido, grande potencial a ser desbravado pela cidadania ecológica brasileira por meio do manuseio da ação popular ambiental.

\subsubsection{AS AUDIÊNCIAS PÚBLICAS JUDICIAIS EM MATÉRIA AMBIENTAL E O} PROTAGONISMO DO STF

O STF tem estabelecido um novo paradigma de participação social no campo judicial, capitaneando (desde 2007) a realização de audiências públicas judiciais, de modo a permitir a participação das diversas partes interessadas, notadamente em questões de grande envergadura social, como comumente ocorre com as questões ecológicas, já que veiculam o interesse de toda a coletividade. Especificamente sobre temas que direta ou indiretamente estão relacionados à proteção ambiental, destacamos as seguintes audiências públicas já realizadas pela nossa Corte Constitucional: 1) Pesquisas com células-tronco embrionárias, em 20 de abril de 2007, referente à ADI 3.510; 2) Importação de pneus usados, em 27 de junho de 2008, referente à ADPF 101; 3) Judicialização do direito à saúde, em 27, 28 e 29 de abril e 4, 6 e 7 de maio de 2009, referente à SL 47, SL 64, STA 36, STA 185, STA 211, STA 278, SS 2.361, SS 2.944, SS 3.345, SS 3.355; 4)

78 Na jurisprudência do STJ, sobre a ação pular ambiental ver: REsp 889.766-SP, rel. Min. Castro Meira, j. 04.10.2007; e REsp 1.252.697/RJ, 2 ${ }^{\mathrm{a}}$ Turma, Rel. Min. Herman Benjamin, j. 27.11.2012 
Proibição do uso de amianto, em 24 e 31 de agosto de 2012, referente à ADI 3.937; 5) Campo Eletromagnético de Linhas de Transmissão de Energia, em 6, 7 e 8 de março de 2013, referente ao RE 627.189; 6) Queima da palha da cana-de-açúcar, 22 de abril de 2013, referente ao RE 586.224; e 7) Novo Código Florestal, em 18 de abril de 2016, referente às ADI n 4.901, ADI n 4.902, ADI n 4.903, ADI n 4.937.

A realização de audiências públicas judiciais pelo STF é um exemplo paradigmático para o nosso Sistema de Justiça, abrindo importantíssimo instrumento de participação pública (e também de acesso à informação) na seara judicial. A temática ecológica, conforme podemos verificar dos exemplos trazidos, tem suscitado temas de grande relevância social e ocupado grande espaço no nosso Poder Judiciário, sendo fundamental que a condução de tais ações judiciais permita a participação pública na tomada de decisões em sede judicial. Esperamos, por certo, que outras instâncias judiciais também se sintam estimuladas a seguir o exemplo do STF e promover audiências públicas judiciais, especialmente no curso de ações coletivas e ações voltadas ao controle concentrado de constitucionalidade que versem sobre a temática ecológica, inclusive em vista da renovação processual capitaneada pelo NCPC. ${ }^{79}$

\subsubsection{A FIGURA DO AMICUS CURIAE ("AMIGO DA CORTE") NAS AÇÕES AMBIENTAIS E A AMPLIAÇÃO DO INSTITUTO TRAZIDA PELO NCPC}

O instituto do amicus curiae, de modo similar ao que tem ocorrido nas audiências públicas judiciais promovidas pelo STF, também tem tido a sua utilização crescente no plano judicial, permitindo que um terceiro interessado (por exemplo, uma entidade ambientalista ou entidade de cunho acadêmico ou científico) intervenha no processo de tomada de decisão judicial, frequentemente, em defesa dos interesses de grupos por ele representados, lançando informações por meio de parecer acerca da questão jurídica controvertida (além da possibilidade de sustentação oral perante a Corte). O fundamento legal do instituto é o art. $7^{\circ}, \S$ $2^{\circ}$, da Lei $9.868 / 99$ (e, mais recentemente, também o art. 138 do NCPC), ao prever que: "o relator, considerando a relevância da matéria e a representatividade dos postulantes, poderá, por despacho irrecorrível, admitir, observado o prazo fixado

79 O NCPC consagrou o instituto da audiência pública ao prevê-la expressamente na regulamentação do incidente de resolução de demandas repetitivas (art. 983, § $1^{\circ}$, e 1.038, II). 
no parágrafo anterior, a manifestação de outros órgãos ou entidades". A função da figura do amicus curaie, de acordo com a lição de Luiz G. Marinoni, "é contribuir para a elucidação da questão constitucional por meio de informes e argumentos, favorecendo a pluralização do debate e a adequada e racional discussão entre os membros da Corte, com a consequente legitimação social da decisão". ${ }^{80}$

O NCPC inovou de forma significativa na matéria ao consagrar expressamente o instituto do amicus curiae, possibilitando sua aplicação para todo o espectro de ações processuais, não mais restrito, portanto, ao plano das ações constitucionais, desde que, é claro, preenchidos os requisitos trazidos pelo diploma processual. De acordo com o art. 138 do NCPC, "o juiz ou o relator, considerando a relevância da matéria, a especificidade do tema objeto da demanda ou a repercussão social da controvérsia, poderá, por decisão irrecorrível, de ofício ou a requerimento das partes ou de quem pretenda manifestar-se, solicitar ou admitir a participação de pessoa natural ou jurídica, órgão ou entidade especializada, com representatividade adequada, no prazo de 15 (quinze) dias de sua intimação". Trata-se de figura sui generis de intervenção processual de terceiro trazida pelo NCPC, mas que, pela relevância e repercussão social inerente às ações que versam sobre a proteção ecológica, é perfeitamente aplicável à matéria ambiental (como em ações civis públicas).

O instituto do amicus curiae em ações coletivas ambientais abre importante "fenda" para a participação de atores, em especial de entidades ambientalistas e entidades científicas, que podem contribuir para o esclarecimento de fatos e informações técnicas, influenciando de forma significativa na formação do convencimento do Estado-Juiz (tanto no primeiro grau quanto em instâncias recursais). É notório o conhecimento técnico ou expertise de algumas entidades da sociedade civil organizada ou mesmo de entidades públicas ou privadas que trabalham nas mais diversas áreas ambientais, de modo que a sua abertura propiciada pelo instituto do amicus curiae para trazer tal informação - muitas vezes, de natureza não jurídica - para a discussão processual travada é importante mecanismo de participação no campo processual, reforçando a própria legitimidade da decisão judicial a ser tomada.

80 SARLET, Ingo W.; MARINONI, Luiz G.; MITIDIERO, Daniel. 5.ed. Curso de direito constitucional. São Paulo: Saraiva, 2016, p. 1110. 


\subsubsection{INVERSÃO DO ÔNUS DA PROVA NAS AÇÕES COLETIVAS AMBIENTAIS}

No âmbito jurisprudencial e de modo afinado com ampliação do acesso à justiça em matéria ambiental, inclusive com o objetivo de assegurar a efetividade do direito à informação, o STJ, a fim de estabelecer um panorama processual mais igualitário e participativo, ${ }^{81}$ tem admitido a inversão do ônus da prova em ação civil pública de natureza ambiental, considerando a relação interdisciplinar entre as normas de proteção ao consumidor e as de proteção ambiental, bem como o caráter público e coletivo do bem jurídico tutelado. Essa interpretação formulada pelo STJ determinou, ao aplicar a extensão das regras de proteção do consumidor para a tutela ecológica e o princípio da precaução, que "compete a quem se imputa a pecha de ser, supostamente, o promotor do dano ambiental a comprovação de que não o causou ou de que não é potencialmente lesiva a substância lançada no ambiente". Resultou consignado também na decisão que "a perícia é sempre necessária quando a prova do fato depender de conhecimento técnico e se recomenda ainda mais na seara ambiental, visto a complexidade do bioma".

O STJ, ao aplicar a inversão do ônus da prova em matéria ambiental, consolidou entendimento extremamente relevante para a resolução de tais pleitos coletivos. Esse entendimento pode ser traduzido até mesmo como um incentivo a que atores privados - notadamente indivíduos e organizações não governamentais voltadas à tutela ecológica, que possuem maior receio de ingressar em juízo por falta de recursos técnicos e econômicos - compareçam, com maior frequência e de forma direta, ao Poder Judiciário, independentemente da intermediação de entes públicos, como é o caso do Ministério Público e da Defensoria Pública. O fortalecimento da atuação da sociedade civil em prol da tutela ecológica seria de todo desejável do ponto de vista democrático e de efetividade da legislação ambiental. Há, por esse prisma, um campo judicial fértil para potencializar ao máximo a participação democrática dos indivíduos e das organizações da sociedade civil no âmbito judicial, bem como lhes assegurar o acesso à informação em matéria ambiental em poder dos entes públicos e,

81 STJ, REsp 1.060.753/SP, 2. ${ }^{a}$ T., rel. Min. Eliana Calmon, j. 01.12.2009. Precedente citado: REsp 1.049.822-RS. No mesmo sentido, inclusive com referência expressa à incidência do princípio da precaução, v. STJ, REsp 972.902RS, 2. ${ }^{\text {a } T u r m a, ~ r e l . ~ M i n . ~ E l i a n a ~ C a l m o n, ~ j . ~ 25.08 .2009 . ~}$ 
por vezes, também os particulares, em vista, sobretudo, da eficácia dos direitos fundamentais nas relações entre particulares, conforme tratamos no tópico sobre o acesso à informação ambiental, inclusive quanto ao efeito de estabelecer a inversão do ônus da prova em ações judiciais ambientais.

\subsubsection{MECANISMOS EXTRAJUDICIAIS DE RESOLUÇÃO DE CONFLITOS AMBIENTAIS (TERMO DE AJUSTAMENTO DE CONDUTA, INQUÉRITO CIVIL E PODER DE REQUISIÇÃO)}

A resolução de conflitos ambientais não está circunscrita apenas à "arena judicial", colocando-se, muitas vezes, na esfera extrajudicial. Nesse sentido, o termo de ajustamento de conduta (TAC) é um dos mais importantes instrumentos de resolução de conflitos coletivos ambientais. O TAC pode ser celebrado tanto no plano extrajudicial, anteriormente à propositura de uma ação civil pública, quanto no plano judicial, ou seja, após a propositura de ação civil pública, quando então é submetido à homologação judicial, pondo termo à ação civil pública ajuizada. É comum, quando o TAC é firmado pelo Ministério Público, que o mesmo se dê no âmbito do processamento do inquérito civil, ainda no plano extrajudicial, após a realização da investigação e do levantamento de dados e informação sobre a questão coletiva envolvida (por exemplo, dano ambiental, etc.). Muito embora a Lei da Ação Civil Pública tenha atribuído legitimidade para a instauração de inquérito civil apenas ao Ministério Público (art. $\left.8^{\circ}, \S 1^{0}\right)^{82}$, e não aos demais entes legitimados para a propositura de ação civil pública, o mesmo não ocorreu no que toca à legitimidade para firmar o TAC. Nesse sentido, dispõe o art. $5^{\circ}$, § 6 , da LACP, incluído pela Lei 8.078/90, que "os órgãos públicos legitimados poderão tomar dos interessados compromisso de ajustamento de sua conduta às exigências legais, mediante cominações, que terá eficácia de título executivo extrajudicial". A legitimidade para a celebração de TAC, conforme está consignado de forma expressa no dispositivo citado, está restrita apenas aos entes públicos legitimados, excluindo-se, de tal sorte, as associações civis.

O inquérito civil (art. $8^{\circ}, \S 1^{\circ}$, da Lei 7.347/85), titularizado pelo Ministério Público, também se configura como importante mecanismo de resolução

82 “Art. $8^{\circ}(\ldots) \S 1^{\circ} \mathrm{O}$ Ministério Público poderá instaurar, sob sua presidência, inquérito civil, ou requisitar, de qualquer organismo público ou particular, certidões, informações, exames ou perícias, no prazo que assinalar, o qual não poderá ser inferior a 10 (dez) dias úteis". 


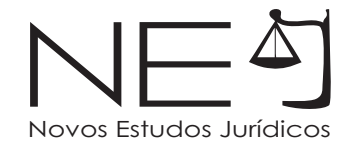

extrajudicial de conflitos ambientais, inclusive oportunizando a celebração de termos de ajustamento de conduta, como referido anteriormente, ou mesmo os atos preparatórios ao ajuizamento de ação civil pública pelo Parquet. No trâmite do inquérito civil, muitas vezes até mesmo aberto em decorrência de representação formulada por representantes da sociedade civil, devemos oportunizar a participação pública, autorizando os interessados (cidadãos individualmente, entidades ambientalistas, entidades científicas, etc.) a acompanhar o seu trâmite e colaborar com o Parquet na apuração dos fatos e adoção das medidas administrativas e judiciais pertinentes.

Na linha dos demais instrumentos destacados, o poder de requisição é outro mecanismo fundamental para possibilitar a resolução extrajudicial de conflitos coletivos ambientais, além, é claro, de oportunizar a devida instrução probatória preparatória para a propositura de ações coletivas por parte dos entes públicos legitimados. Muitas vezes, a partir da obtenção de informações por requisição junto às autoridades públicas e melhor compreensão das questões envolvidas em determinado caso de violação a direitos coletivos, tornam-se viáveis a negociação e a celebração de TAC, evitando-se a judicialização. Mas, por óbvio, quando não se fizer possível a resolução extrajudicial, o poder de requisição também é elemento-chave para a obtenção de dados e informações de órgãos públicos para viabilizar a propositura de ação judicial. Sem dúvida, a gênese do poder de requisição está contida no próprio art. 50, XXXIII, da CF/88, o qual assegura a todos o direito de receber dos órgãos públicos informações de seu interesse particular. A respeito do tema, vale frisar que, na absoluta maioria das vezes, o uso do poder de requisição no âmbito da tutela ecológica estará vinculado à tutela e à promoção de direitos fundamentais, sendo, de tal sorte, expressão do direito de petição. Mais recentemente, a Lei de Acesso à Informação (Lei 12.527/2011) também veio a reforçar normativamente o poder de requisição para a obtenção de informações em poder dos órgãos públicos, ao assinalar, no seu art. 21, que "Não poderá ser negado acesso à informação necessária à tutela judicial ou administrativa de direitos fundamentais". 


\subsubsection{A ASSISTÊNCIA JURÍDICA EM FAVOR DAS ENTIDADES DA SOCIEDADE CIVIL E DAS PESSOAS NECESSITADAS EM MATÉRIA AMBIENTAL}

Outro tema relevante pelo prisma do acesso à justiça em matéria ambiental diz respeito à assistência jurídica, tanto aos cidadãos do ponto de vista individual quanto às entidades ambientalistas em termos coletivos. A razão principal para a concessão de assistência jurídica diz respeito à transposição de barreiras, especialmente as de natureza econômica e técnica, que impedem que os indivíduos e as entidades ambientalistas possam valer-se dos instrumentos jurídicos, extrajudiciais e judiciais, com o propósito de promoverem a proteção do ambiente. Conforme a lição de Álvaro L. Valery Mirra, "só dessa maneira, com a assistência jurídica e judiciária integral e gratuita aos indivíduos e entes representativos dos interesses da coletividade na proteção do meio ambiente, associada a um regime financeiro que lhes seja favorável no processo coletivo, terse-á condições de assegurar, na sua inteireza, o acesso participativo à justiça na área ambiental, sem os obstáculos jurídicos e econômicos que tradicionalmente inibem iniciativas judiciais e extrajudiciais da sociedade civil". 83

A Convenção de Aarhus (1998), sensível à tal questão limitadora do acesso à justiça em matéria ambiental, prevê que o Estado "assegurará a disponibilização ao público das informações relativas ao acesso aos processos de recursos administrativos e judiciais e considerará a possibilidade de estabelecer mecanismos de assistência adequados para eliminar ou reduzir os óbices financeiros e outros ao acesso à justiça (art. 9. $\left.{ }^{\circ}, 5\right)^{\prime \prime}$. No cenário legislativo brasileiro, a assistência jurídica às entidades ambientalistas pode ser compreendida com base no art. $4^{\circ}$ da LC 80/94 (Lei Orgânica Nacional da Defensoria Pública) ${ }^{84}$, com redação dada pela LC 132/2009, ao dispor que se trata de função institucional da Defensoria Pública "exercer, mediante o recebimento dos autos com vista, a ampla defesa e o contraditório em favor de pessoas naturais e jurídicas, em processos administrativos e judiciais, perante todos os órgãos e em todas as instâncias, ordinárias ou extraordinárias,

83 MIRRA, Participação, processo civil e defesa do meio ambiente..., p. 579.

84 A respeito da questão, merece destaque a ADI 4.636 interposta pelo Conselho Federal da OAB no STF, impugnando o inciso $V$ do art. $4^{\circ}$ da LC 80/94, por força da redação que lhe foi conferida pela LC 132/2009, com o propósito de vedar que as pessoas jurídicas sejam assistidas judicialmente pela Defensoria Pública. Na ADI 4.636, ainda pendente de julgamento, inclusive no tocante à medida cautelar, já há parecer da PGR no sentido da sua improcedência. 
utilizando todas as medidas capazes de propiciar a adequada e efetiva defesa de seus interesses" (inciso V), bem como "promover a mais ampla defesa dos direitos fundamentais dos necessitados, abrangendo seus direitos individuais, coletivos, sociais, econômicos, culturais e ambientais, sendo admissíveis todas as espécies de ações capazes de propiciar sua adequada e efetiva tutela" (inciso X).

Assim, fica evidenciado que também as pessoas jurídicas (e, particularmente, as associações ambientalistas), com fins lucrativos ou não, podem fazer jus ao benefício da assistência jurídica prestada pela Defensoria Pública, desde que, é claro, conforme inclusive entendimento do STJ85, comprovada efetivamente a insuficiência de recursos financeiros. A prestação de assistência jurídica pela Defensoria Pública em prol de determinadas pessoas jurídicas (organizações não governamentais ambientais, associações de bairro voltadas à proteção do patrimônio histórico e cultural, movimentos populares de base que tem entre as suas bandeiras a proteção do ambiente, etc.) nos parece coadunar perfeitamente com os seus objetivos institucionais.

A mesma situação também verificamos no caso do cidadão individual para o ajuizamento de ação popularambiental. De modo complementarao reconhecimento normativo da legitimidade ativa atribuída ao cidadão pela legislação constitucional e infraconstitucional, há a necessidade de amparo técnico-jurídico (inclusive em termos de capacidade postulatória) para o ajuizamento da ação popular, tornando essencial a assistência jurídica para viabilizar a efetividade de tal instrumento processual coletivo, notadamente para a hipótese de o cidadão legitimado não possuir condições econômicas de contratar um advogado particular. É nesse contexto que entra em cena a importância de a Defensoria Pública, ou seja, para assegurar a assistência jurídica ao cidadão necessitado para a propositura de ação popular no campo ambiental. ${ }^{86}$

2.4.8. CRIAÇÃO DE JUSTIÇA ESPECIALIZADA EM MATÉRIA AMBIENTAL

A criação de justiça especializada na temática ecológica é, sem dúvida, um passo importante na efetivação do acesso à justiça em matéria ambiental, 85 STJ, REsp 554840/MG, 4a Turma, Rel. Min. Aldir Passarinho Junior, j. 16.09.2004.

86 De modo a reconhecer a possibilidade de a Defensoria Pública interpor ação popular ambiental conjuntamente com o cidadão, v. MIRRA, Participação, processo civil e defesa do meio ambiente..., p. 330-331. 
inclusive como expressão da dimensão organizacional e procedimental do direito fundamental ao ambiente e dos correlatos deveres estatais de proteção para com este último. A criação de varas especializadas no primeiro grau de jurisdição, tanto na justiça estadual quanto federal (e, em alguns casos, até mesmo com juizados itinerantes), e também nos Tribunais em matéria de tutela ambiental, contando com uma estrutura organizacional e técnica adequada e em condições efetivas de dar conta de forma qualificada da crescente demanda na temática, representa um grande passo para a efetivação da legislação ambiental. A justiça especializada ambiental em questão já se trata de realidade em algumas localidades. A título de exemplo, o Tribunal de Justiça do Estado de São Paulo, por meio da Resolução 240/2005, aprovada pelo seu Órgão Especial, criou a Câmara Especial de Meio Ambiente (hoje, na prática, são duas Câmaras), seguindo o exemplo das Varas Ambientais Federais existentes em Curitiba, Florianópolis e Porto Alegre.

O aperfeiçoamento de um sistema integrado e cooperativo de informação segura e atualizada e de gestão em matéria de políticas ambientais, notadamente no contexto de um regime federativo, acaba sendo indispensável para servir de baliza para a própria atuação do Poder Judiciário e para a redução da margem de erros no processo decisório administrativo e jurisdicional, que depende da qualidade das informações. Igualmente importante o investimento permanente na adequada formação dos quadros do Poder Judiciário para atuação em matéria ambiental, especialmente pelo forte conteúdo interdisciplinar dos problemas a serem enfrentados e a necessária capacidade de avaliação de laudos periciais complexos. Não há dúvida que o aperfeiçoamento técnico de Juízes na temática ecológica, para além até mesmo do próprio Direito Ambiental, trará como reflexo decisões judiciais mais fundamentadas e adequadas à complexidade técnica que envolve os conflitos ambientais.

CONSIDERAÇÕES FINAIS

Comocorolário da própria proteçãoconstitucional denaturezajusfundamental conferida ao meio ambiente pela CF/88 e dos direitos ambientais procedimentais, parece-nos correto que os Juízes e os Tribunais (em outras palavras, o EstadoJuiz) devam assumir postura mais participativa, de modo a relativizar o princípio 
do impulso oficial ${ }^{87}$, em virtude da relevância social do tema, bem como por se tratar, na grande maioria das vezes, de pleito que envolve direito indisponível, o que repercute, inclusive, na produção de provas, justificando a possibilidade de inversão do ônus probatório, de modo a privilegiar a "paridade de armas" e uma relação mais equânime entre as partes, já que muitas vezes verificamos um grande desequilíbrio técnico e econômico entre as mesmas. ${ }^{88}$ Essa intervenção judicial trata-se, em verdade, não de um "poder", mas sim de um "dever" constitucional do agente político investido do papel de prestar a jurisdição, haja vista o seu compromisso com a efetividade do processo e a tutela ecológica (art. 225 da CF/88).

Ademais disso, tendo em conta que dentre os meios de o Estado cumprir com os seus deveres de proteção está o de criar procedimentos e técnicas adequadas à tutela efetiva dos direitos, cabe também ao Poder Judiciário o papel de interpretar a legislação processual de um modo compatível com as exigências da proteção suficiente, mediante o recurso, dentre outros, à técnica da interpretação conforme a Constituição, ou mesmo declarando a inconstitucionalidade da legislação processual, crescendo, nesse contexto, os poderes (mas também a responsabilidade) dos Juízes e dos Tribunais. Não por outra razão, o princípio "favor debilis" (e o mesmo se pode dizer em relação ao princípio "in dubio pro natura"89) tem sido aplicado em matéria ambiental pelo Superior Tribunal de Justiça, com o propósito de facilitar o acesso à justiça e assegurar maior paridade na relação processual (por exemplo, mediante a inversão do ônus da prova). ${ }^{90}$ Em última instância, essa postura ativa do Poder Judiciário em sintonia com os direitos ambientais procedimentais, sobretudo quando estivermos diante de pleito que envolva violação ou ameaça de violação ao direito fundamental ao ambiente. Isso, por certo, implica a ampliação dos canais de acesso ao nosso Sistema de Justiça e, consequentemente, assegura uma maior participação social

87 Na doutrina, v. DIDIER JR.; Fredie; ZANETI JR.; Hermes. 10.ed. Curso de direito processual civil (Vol. 4, Processo Coletivo). 10.ed. Salvador: Juspodium, 2016, p. 34 e ss.

88 Sobre a distribuição equânime do ônus da prova na perspectiva processual-ambiental, v. SARAIVA NETO, Pery. A prova na jurisdição ambiental. Porto Alegre: Livraria do Advogado, 2010, especialmente p. 135 e ss.

89 Na jurisprudência do STJ, acerca do princípio "in dubio pro natura”, v., entre outros julgados: REsp 1.114.893/ MG, $2^{a}$ Turma, Rel. Min. Herman Benjamin, j. 16.03.2010; e REsp 1.367.923 /RJ, $2^{\mathrm{a}}$ Turma, Rel. Min. Humberto Martins, j. 27.08.2013. Defendendo em sede doutrinária o reconhecimento do princípio "in dubio pro ambiente", inclusive à luz de uma hermenêutica jurídica ecológica, v. BELCHIOR, Germana Parente Neiva. Hermenêutica jurídica ambiental. São Paulo: Saraiva, 2011, p. 265. Outra vertente do referido princípio pode ser identificada no princípio da primazia dos interesses futuros, tomando por base a proteção das futuras gerações (RAMOS JR., Dempsey Pereira. Meio ambiente e conceito jurídico de futuras gerações. Curitiba: Juruá, 2012, p. 369 e ss.). 
(bem informada) no controle de práticas públicas e privadas que atentem contra o equilíbrio ecológico, tendo por premissa a efetivação da legislação ambiental à luz de uma cidadania ecológica.

\section{REFERÊNCIAS DAS FONTES CITADAS}

ALEXY, Robert. Teoria dos direitos fundamentais. Tradução de Virgílio Afonso da Silva. São Paulo: Malheiros, 2008.

ANTON, Donald K.; SHELTON, Dinah L. Environmental protection and human rights. Cambridge: Cambridge University Press, 2011.

ANTUNES, Luís Filipe Colaço. Direito público do ambiente. Lisboa: Almedina, 2008.

O procedimento administrativo de avaliação de impacto ambiental: para uma tutela preventiva do ambiente. Coimbra: Almedina, 1998.

AYALA, Patryck de Araújo. Devido processo ambiental e o direito fundamental ao ambiente. Rio de Janeiro: Lumen Juris, 2011.

BARCELLOS, Ana Paula de. A eficácia jurídica dos princípios constitucionais: o princípio da dignidade humana. 2.ed. Rio de Janeiro/São Paulo/Recife: Renovar, 2008.

BELLO FILHO, Ney de Barros. Direito ao ambiente: da compreensão dogmática do direito fundamental na pós-modernidade. Porto Alegre: Livraria do Advogado, 2012.

BENJAMIN, Antonio Herman. "Constitucionalização do ambiente e ecologização da Constituição brasileira". In: CANOTILHO, José Joaquim Gomes; MORATO LEITE, José Rubens (Orgs.). Direito constitucional ambiental brasileiro. São Paulo: Saraiva, 2007, p. 76 e ss.

BELCHIOR, Germana Parente Neiva. Hermenêutica jurídica ambiental. São Paulo: Saraiva, 2011. BERTHIER, A.; KRÄMER. The Aarhus Convention: Implementation and Compliance in European Union Law. Bruxelas: ClientEarth, 2014.

BIM, Eduardo Fortunato. Audiências públicas. São Paulo: Revista dos Tribunais, 2014.

BITENCOURT NETO, Eurico. O direito ao mínimo para uma existência digna. Porto Alegre: Livraria do Advogado, 2010.

BOBBIO, Norberto. A era dos direitos. 10.ed. Rio de Janeiro: Campus, 1992.

CAPPELLETTI, Mauro; e GARTH, Bryant. Acesso à justiça. Porto Alegre: Fabris, 1988.

; GORDLEY, James; JOHNSON, Earl. Toward equal Justice: a comparative study of legal aid in modern societies. Milan: Giufre Editore, 1975.

(Org.). Acess to Justice and Welfare State. Florença: European University Institute, 1981. 
CANOTILHO, J. J. Gomes. "O direito ao ambiente como direito subjetivo". In: CANOTILHO, José Joaquim Gomes. Estudos sobre Direitos Fundamentais. Coimbra: Coimbra Editora, 2004, p. 187 e ss.

COMISSÃO MUNDIAL SOBRE MEIO AMBIENTE E DESENVOLVIMENTO. Relatório Nosso Futuro Comum. 2.ed. São Paulo: Editora da Fundação Getúlio Vargas, 1991.

DIAS, Inês de Souza; CAPOBIANCO, João Paulo. "As organizações não-governamentais e a legislação ambiental: a experiência da Fundação SOS Mata Atlântica". In: BENJAMIN, Antônio Herman (Coord.). Dano ambiental: prevenção, reparação e repressão. São Paulo: Revista dos Tribunais, 1993, p. 394 e ss.

DIDIER JR.; Fredie; ZANETI JR.; Hermes. 10.ed. Curso de direito processual civil (Vol. 4, Processo Coletivo). 10.ed. Salvador: Juspodium, 2016.

DINAMARCO, Cândido Rangel. A instrumentalidade do processo. 13.ed. São Paulo: Malheiros, 2008.

EBBESSON, Jonas. "Acesso à informação, participação pública e acesso à justiça em matéria ambiental: uma breve introdução à Convenção de Aarhus". In: Revista de Direito Ambiental, v. 64, São Paulo, Revista dos Tribunais, Out.-Dez., 2011, p. 35 e ss.

"Public participation". In: BODANSKY, Daniel; BRUNNÉE, Jutta; HEY, Ellen (Edit.). The Oxford Handbook of International Environmental Law. New York: Oxford University Press, 2007, p. 687 e ss.

ERBGUTH, Wilfried; SCHLACKE, Sabine. Umweltrecht. 5.ed. Baden-Baden: Nomos, 2014.

FENSTERSEIFER, Tiago. Direitos fundamentais e proteção do ambiente. Porto Alegre: Livraria do Advogado, 2008.

. Defensoria Pública, direitos fundamentais e ação civil pública. São Paulo: Saraiva, 2015.

. Defensoria Pública na Constituição Federal. Rio de Janeiro: GEN/Forense, 2017.

; SARLET, Ingo W. Direito constitucional ambiental. 5. ed. São Paulo: Revista dos Tribunais, 2017.

; SARLET, Ingo W. Direito ambiental: introdução, fundamentos e teoria geral (São Paulo: Saraiva, 2014.

; SARLET, Ingo W. Princípios do direito ambiental. 2. ed. São Paulo: Saraiva, 2017.

; SARLET, Ingo W.; MACHADO, Paulo Affonso Leme. Constituição e legislação ambiental comentadas. São Paulo: Saraiva, 2015.

GABEIRA, Fernando et all. Partido Verde: propostas de ecologia política. Rio de Janeiro: Editora Anima, 1986. 
GOMES, Carla Amado. Risco e modificação do ato autorizativo concretizador de deveres de proteção do ambiente. Coimbra: Coimbra Editora, 2007.

. A prevenção à prova no direito do ambiente. Coimbra: Coimbra Editora, 2000.

. "Legitimidade processual popular, litispendência e caso julgado". In: A Trilogia de Aarhus. GOMES, Carla Amado; ANTUNES, Tiago (Coords.). Lisboa: Instituto de Ciências Jurídico Políticas/ Universidade de Lisboa, 2015, p. 78 e ss. Disponível em: http://icjp.pt/sites/default/ files/publicacoes/files/ebook_trilogia_aarhus.pdf. Acesso em: 27 de março de 2017.

HÄBERLE, Peter. "Grundrechte im Leistungsstaat". In: VVDStRL, 1972, p. 81 e ss.

HESSE, Konrad. Elementos de direito constitucional da República Federal da Alemanha. Porto Alegre: Sergio Antônio Fabris Editor, 1998.

HIPPEL, Eike von. Der Schutz des Schwächeren. Tübingen: J.C.B.Mooh, 1982.

HUFEN, Friedhelm. Staatsrecht II: Grundrechte. 4.ed. Munique: C.H.Beck, 2014.

KISS, Alexandre; SHELTON, Dinah. Guide to international environmental law. Leiden/Boston: Martinus Hijhoff Publishers, 2007.

KRÄMER, Ludwig. "The Aarhus Convention and EU law". In: A Trilogia de Aarhus. GOMES, Carla Amado; ANTUNES, Tiago (Coords.). Lisboa:Instituto de Ciências Jurídico Políticas/ Universidade de Lisboa, 2015, p. 3 ess. Disponível em: http://icjp.pt/sites/default/files/publicacoes/files/ ebook_trilogia_aarhus.pdf. Acesso em 27 de março de 2017.

MACHADO, Paulo Affonso Leme. Direito à informação e meio ambiente. São Paulo: Malheiros, 2006.

MARINONI, Luiz Guilherme. Teoria Geral do Processo. São Paulo: Revista dos Tribunais, 2006. MARQUES, Cláudia Lima; MIRAGEM, Bruno. O novo direito privado e a proteção dos vulneráveis. São Paulo: Revista dos Tribunais, 2012.

MILARÉ, Édis. Direito do ambiente. 8.ed. São Paulo: Revista dos Tribunais, 2013.

MIRRA, Álvaro Luiz Valery. Participação, processo civil e defesa do meio ambiente. São Paulo: Letras Jurídicas, 2011.

. Impacto ambiental: aspectos da legislação brasileira. 2.ed. São Paulo: Editora Juarez de Oliveira, 2002.

PALLEMAERTS, Marc. "Proceduralizing environmental rights: the Aarhus Convention on Access to Information, Public Participation in Decision-Making and Access to Justice in Environmental Matters in a Human Rights Context". In: Human Rights and the Environment: Proceedings of a Geneva Environment Network roundtable. Genebra: UNEP, 2004, p. 19. Disponível em: http:// www.genevaenvironmentnetwork.org/?q=en/publications. Acesso em 25 de outubro 2017. 
PEREIRA DA SILVA, Vasco. Verde cor de direito: lições de Direito do Ambiente. Coimbra: Almedina, 2002.

PRIEUR, Michel. Droit de l'environnement. 6.ed. Paris: Dalloz, 2011.

PURVIN DE FIGUEIREDO, Guilherme José. A propriedade no direito ambiental. 3.ed. São Paulo: Revista dos Tribunais, 2008.

RAMOS JR., Dempsey Pereira. Meio ambiente e conceito jurídico de futuras gerações. Curitiba: Juruá, 2012.

RODRIGUES, Marcelo Abelha. Processo civil ambiental. São Paulo: Revista dos Tribunais, 2008. SARAIVA NETO, Pery. A prova na jurisdição ambiental. Porto Alegre: Livraria do Advogado, 2010.

SARLET, Ingo W. A eficácia dos direitos fundamentais. 12. ed. Porto Alegre: Livraria do Advogado, 2015),

. Dignidade da pessoa humana e direitos fundamentais na Constituição Federal de 1988 (10. ed. Porto Alegre: Livraria do Advogado, 2015)

; MARINONI, Luiz Guilherme; MITIDIERO, Daniel Curso de direito constitucional. 6. ed. São Paulo: Saraiva, 2017.

(Org.). Constituição, direitos fundamentais e direito privado. 3.ed. Porto Alegre: Livraria do Advogado, 2011.

SCHLACKE, Sabine; SCHRADER, Christian; BUNGE, Thomas. Informationsrechte, Öffentlichkeitsbeteiligung und Rechtsschutz im Umweltrecht (Aarhus-Handbuch). Berlin: Erich Schmidt Verlag, 2010.

TORRES, Ricardo Lobo. O direito ao mínimo existencial. Rio de Janeiro: Renovar, 2009.

Recebido em: março/2018

Aprovado em: julho/2018 